\title{
PRÁVA A POVINNOSTI UHORSKÝCH BISKUPOV PRI SPRÁVE DIECÉZ V 11. AŽ 14. STOROČÍ Z POHLADU KÁNONICKÉHO PRÁVA'
}

\author{
The Rights and Duties of Bishops from the Kingdom of Hungary \\ in the Administration of Dioceses in the 11 th - 14th Centuries as Related \\ to the Canon Law
}

\author{
Miroslav Glejtek
}

DOI: 10.17846/CL.2018.11.1.79-104

\begin{abstract}
GLEJTEK, Miroslav. The Rights and Duties of Bishops from the Kingdom of Hungary in the Administration of Dioceses in the 11th - 14th Centuries as Related to the Canon Law. Diocesan archbishops and bishops were the most prominent representatives of the medieval Catholic Church in Central Europe. They were responsible for the religious life of their archdiocese or diocese. Only an appointed bishop holds power in pontificalibus, in spiritualibus and in temporalibus. After episcopal ordination, they were authorized to perform sacral acts. The status of bishops, in terms of religious governance and property administration, was derived predominantly from the canon law. Universal canon law collections, conciliar decrees and some elements of secular law determine the fundamental rights and obligations of these prelates. The paper presents the most important of them and supplements them with specific cases from the territory of medieval Kingdom of Hungary.
\end{abstract}

Keywords: bishop, jurisdiction, canon law, Kingdom of Hungary, Middle Ages

\begin{abstract}
Abstrakt: GLEJTEK, Miroslav. Práva a povinnosti uhorských biskupov pri správe diecéz v 11. $a z ̌$ 14. storočí z pohladu kanonického práva. Medzi najvýznamnejších predstavitelov stredovekej katolíckej cirkvi v strednej Európe patrili sídelní arcibiskupi a biskupi. Tí niesli zodpovednost' za náboženský život na území zverenej arcidiecézy alebo diecézy. Len riadne ustanovený biskup bol nositelom plnosti moci in pontificalibus, in spiritualibus a in temporalibus. Na vykonávanie sakrálnych úkonov získavali oprávnenie udelením biskupského svätenia. Postavenie biskupov v oblasti duchovnej a majetkovej správy vychádzali najmä z noriem kanonického práva. Univerzálne kanonicko-právne zbierky, ustanovenia koncilov a niektoré prvky svetského práva určujú základné práva a povinnosti týchto prelátov. V predloženom texte sú najvýznamnejšie z nich predstavené a doplnené o konkrétne prípady z územia stredovekého Uhorského královstva.
\end{abstract}

Klúčové slová: biskup, jurisdikcia, kanonické právo, Uhorské královstvo, stredovek

1 Štúdia vznikla na Katedre histórie FF UKF v Nitre v rámci riešenia projektu VEGA č. 1/0006/18 Imago episcopi - moc biskupa a jej prezentácia v stredoveku. 


\section{Úvod}

Neoddelitel’nou súčastou života stredovekej stredoeurópskej spoločnosti bola na všetkých úrovniach latinská cirkev reprezentovaná rímskym biskupom - pápežom. Za dlhé stáročia, počas ktorých sa bádatelia zaoberajú obdobím stredoveku, vznikli tisíce prác najrôznejšieho rozsahu a úrovne, ktoré sa zaoberajú miestom, postavením, fungovaním a úlohami, ktoré cirkev prostredníctvom svojich reprezentantov (vyššieho kléru) v spoločnosti zastávala. Rozmanitost látky a bádatel'ských prístupov sú úmerné obrovskej škále aktivít cirkvi naprieč spoločenskými a sociálnymi skupinami, a geografickým priestorom. Panovníckym dvorom počínajúc a vidieckou farnostou či izolovaným kláštorom končiac. Tieto aktivity ponúkajú takmer nevyčerpatelné množstvo čiastkových tém dotýkajúcich sa vnútorného fungovania vo vnútri cirkvi, ako aj vo vztahu k sekulárnemu (laickému) prostrediu. Pochopitelne v možnostiach a limitoch zachovaných prameňov.

$\mathrm{Na}$ nasledujúcich riadkoch budem venovat' pozornost̉ špecifickej skupine predstavitelov stredovekých náboženských elít. Boli to (arci)biskupi, ako najvyšší reprezentanti katolíckeho krestanstva, stojaci na čele cirkevnej hierarchie. Ak opomenieme opátov a priorov najväčších a najvplyvnejších kláštorov či prepoštov kapitúl, sú stredovekí biskupi najviditelnejšími nositelmi a reprezentantmi moci v cirkvi, ako aj vo vzt̉ahu k profánnemu svetu. Vychádzajúc z princípu, že arcibiskupi mali v rámci vlastnej arcidiecézy automaticky rovnaké práva ako biskupi v diecézach, budem pre zjednodušenie používat len termín biskup a biskupstvo (diecéza). Len v prípade zdôraznenia niektorých špecifických práv a povinností prináležiacich výlučne arcibiskupom ako metropolitom, najmä vo vztahu k podriadeným zložkám cirkevnej správy budem používat termín arcibiskup (arcidiecéza).

Spomenutí preláti ${ }^{2}$ tvorili exkluzívne spoločenstvo, či inými slovami profesijnú skupinu, ktorá v Uhorskom královstve nikdy v jednom období nepresiahla počet niekolkých jednotlivcov. V zásade bol ich počet definovaný počtom (arci)diecéz, ${ }^{3} \mathrm{v}$ ktorých ako (arci)biskupi pôsobili. ${ }^{4} \mathrm{~K}$ nim treba pripojit ešte prípadných pomocných biskupov. Špecifickú skupinu predstavovali preláti z iných krajín, ktorí v Uhorsku pôsobili v pozícii pápežských legátov s najrôznejšími právomocami

2 Z hladiska cirkevného práva boli prelátmi aj další cirkevní hodnostári ako opáti a priori, prepošti a hodnostári kapitúl (Uličný 2013, 339). V rámci tejto štúdie budeme hovorit o užšej skupine najvyššie postavených prelátov, arcibiskupov a biskupov. Tieto dve skupiny hodnostárov chápe ako uhorských prelátov aj renovácia zlatej buly z r. 1231: „Prelati ecclesiarum ut archiepiscopi et episcopi...“ (CDSL I 1971, č. 375, 267).

3 V Uhorsku sa v stredoveku vyprofilovali dve arcidiecézy. Do rozsiahlejšej ostrihomskej prináležali sufragánne Nitrianske, Jágerské, Rábske, Vesprímske, Pätkostolské a Vacovské biskupstvo. Druhému metropolitovi, v Kaloči, podliehali Čanádske, Varadínske, Sedmohradské, Bosnianske, Sriemske a Záhrebské biskupstvo. Pre úplnost̉ môžeme doplnit ešte tretiu, Splitskú arcidiecézu, ku ktorej náležali Zadarské a Dubrovnícke biskupstvo, ako aj dalšie diecézy v Dalmácii (Érszegi 1994, 563-564; Eubel 1914, 284). Aj ich hodnostári bývajú, v súlade s politickou situáciu a záujmami uhorských panovníkov v 14. storočí, tiež uvádzaní medzi uhorskými prelátmi.

4 O štruktúre biskupského zboru nás bohato informujú napríklad slávnostné panovnícke privilégiá, v ktorých sú uvádzaní v zoznamoch královských hodnostárov. Ako príklad nám môže poslúžit listina Ludovíta I. z r. 1355, v ktorej záverečnej časti sa uvádza: „... venerabilibus in Christo patribus dominis: eodem Nicolao Strigoniensi, locique eiusdem comite perpetuo, fratre Dyonisio Cholocensi et Dominico Spalatensi archiepiscopis; Nicolao Agriensis, Demetrio Waradiensis, Andrea Transilvano, Colomano Jauriensis, Nicolao Quinqueecclesiensis, Michaele Vaciensis, Johanne Wespremiensis, Thoma Chanadiensis, fratre Thoma Sirimiensis, Peregrino Bosznensis, Stephano Nitriensis et Blasio Tininiensis ecclesiarum episcopis, ecclesias Dei salubriter gubernantibus..." (Frankói 1899, 138). Velmi lahko si môžeme takýmto spôsobom, pomocou královských listín, overit aktuálne zloženie biskupského zboru, ak to zachovaný pramenný materiál, pochopitelne, dovoluje. 
a povereniami. Tí však netvorili stabilnú súčast' uhorského episkopátu (Kalous 2014, 347-355; Kalous 2010).

V rámci príspevku sa zameriam na najvýznamnejšie úlohy, ktoré títo preláti v stredovekej spoločnosti plnili v oblasti duchovnej (in spiritualibus) a majetkovej správy (in temporalibus). Mnohé z nich biskupi často delegovali aj na svojich vikárov či iných zástupcov. Pôvodcami týchto práv ale vždy boli diecézni biskupi, či už ich zverovali do kompetencie iných osôb alebo nie. Jedným zo základných zdrojov poznania týchto práv a povinností boli normy kánonického práva, ktorými sa katolícka cirkev riadila ako autonómna organizácia. Tie v najväčšej miere determinovali postavenie biskupov $\mathrm{v}$ cirkvi všeobecne. $\mathrm{V}$ rámci možností ich doplním o príklady z uhorského prostredia. Hned’v úvode považujem za potrebné povedat, že ide o základný prehlad. Každú z načrtnutých tém je možné a potrebné dalej študovat samostatne.

Osobitnú a rozsiahlu problematiku predstavujú práva a povinnosti biskupov in pontificalibus. Sú to všetky sakrálne úkony, ktoré boli biskupi oprávnení vykonávat až získaním najvyššieho posvätného rádu - biskupskou vysviackou. Definuje ich napríklad dielo Panormia, pripisované kanonistovi Ivovi zo Charters: „K rádu biskupa patrí vysväcovanie kostolov, pomazávanie oltárov a posväcovanie krizmy. On ustanovuje uvedené úrady a vysluhuje cirkevné rády, on požehnáva sväté panny a kým určuje každé jedno v jednotlivostiach, tak sám je vo všetkom predstavený." (Rábik 2014, 24) K najexkluzívnejším pontifikálnym právomociam nepochybne patrilo právo udel’ovat všetky stupne svätenia či svätenie krizmy. Mnohé z d’alších obradov mohli vykonávat aj ostatní klerici $\mathrm{s}$ nižšími stupňami svätenia $\mathrm{v}$ prípade, že na to dostali biskupovo poverenie, resp. ich $\mathrm{k}$ tomu všeobecne splnomocňovalo kánonické či miestne zvykové právo. Aj ked’ sú úkony, na ktoré mali prednostné právo diecézni biskupi, ako napríklad posviacky sakrálnych objektov, cintorínov, slávnostné investitúry $\mathrm{k}$ benefíciám a pod. Biskupi často vysluhovali najrôznejšie náboženské obrady pre potreby najvyššie postavených osôb v královstve. Medzi najprestížnejšie patrili pomazania panovníkov pri korunovácii, ale aj vykonávanie krstov či pohrebov v královskej rodine. Až udelením biskupského svätenia sa mohol cirkevný hodnostár plnohodnotne ujat’ správy diecézy vo všetkých záležitostiach. Touto problematikou sa bližšie zaoberat nebudem. Len poznamenám, že ani získanie najvyššieho stupňa svätenia automaticky znamenalo, že prelát má plnú moc in spiritualibus a in temporalibus. Ide o pomocných biskupov, ktorí boli vikármi diecézneho biskupa (vicarius in pontificalibus). Ich počet nebol nikdy stabilný a závisel od aktuálnych potrieb príslušnej diecézy. Zatial čo vikármi v záležitostiach duchovnej a svetskej správy mohli byt’ akýkolvek klerici $\mathrm{s}$ nižšími stupňami svätenia, pri špecifických liturgických úkonoch udelovaných z moci plnosti kňazstva alebo rezervovania kánonickými právom, mohol diecézneho biskupa nahradit zas len ním poverený biskup (Mályusz 2007, 174). ${ }^{5}$ Či už išlo o svätenie oltárov, kostolov, cintorínov, ale aj vydávanie rôznych nariadení, cez vedenie synod, rušenie exkomunikácií až po prípravy krizmy počas obradov Zeleného štvrtka. $K$ ich väčšiemu rozšíreniu došlo najmä od 14 . storočia. Často boli príslušníkmi reholných rádov, resp. boli vyberaní z prostredia členov kapitúl. Ich výskum je však pomerne problematický a v prameňoch sa vo väčšej miere začínajú objavovat v 15 . storočí. Napríklad T. Fedelesovi sa podarilo rekonštruovat medzi rokmi 1402 až 1526 v Pätkostolskej diecéze piatich pomocných biskupov. Z toho boli dvaja príslušníkmi rádu karmelitánov, dvaja členmi katedrálnej kapituly a jeden bol komendátorom benediktínskeho opátstva (Fedeles 2010, 5-20). V Ostrihomskej arcidiecéze sa podarilo medzi rokmi 1458 a 1526 rekonštruovat prítomnost' 12 pomocných biskupov, z ktorých niektorí pôsobili vo funkcii aj viacero období, resp. sa ich úlohy

Ilustruje to listina z r. 1424, ktorá hovorí o tom, že „Nicolaus, Dei et apostolicae sedis gratia episcopus Dionysiensis, suffraganeusque almae ecclesie Agriensis, in pontificalibus generalis" udelil kňazské svätenie „ex mandato et commissione reverendi in Christo Patris et Domini Petri de Rozgon, ecclesiae episcopi Agriensis"(CDH X/6 1844, č. CCLXXIV, 621-622). 
v prameňoch v rôznych obdobiach líšia (Tóth 2014, 14-19). V dalšom texte upriamim pozornost' výlučne na „riadnych“ diecéznych biskupov, s plnostou moci vo všetkých oblastiach.

\section{Základné pramene štúdia právomocí biskupov}

V stredovekom Uhorsku vychádzali práva a povinnosti najvyšších cirkevných hodnostárov v základných otázkach cirkevnej jurisdikcie predovšetkým zo širokého spektra noriem kánonického práva a zvyklostí v katolíckej cirkvi. Tie podobne ako tomu bolo aj v ostatných stredoeurópskych a západoeurópskych štátoch, podliehali Apoštolskej stolici v Ríme (resp. Avignone). Osobitné miesto má v rámci kodifikácie práv a povinností biskupov najmä Graciánov dekrét (1. pol. 12. stor.), neskôr doplnený o Dekretále Gregora IX. (1. pol. 13. stor.), a niektoré dalšie všeobecne uznávané dokumenty kánonického práva (Vladár 2017, 273-286, 302-306; Vladár 2009, 128-156; Mrkývka - Veselá 1992, 38-43; CIC I 1959; CIC II 1959). Ďalším významným zdrojom univerzálneho kánonického práva boli najmä uznesenia všeobecných cirkevných koncilov (DSP II 2007; DSP III 2007). Zákony promulgované na konciloch sa často venovali novým aktuálnym problémom a otázkam, a s právnymi zbierkami sa vzájomne doplňajú. ${ }^{6}$ Zvrchované postavenie noriem kánonického práva definuje aj univerzálne práva a povinnosti biskupov podliehajúcim Apoštolskej stolici. Treba ale zdôraznit, že tieto normy znamenajú určitý ideál. Ten sa ale presadzoval len postupne a mohol sa od reality viac či menej vzd’alovat'. Treba mat' stále na pamäti, že možnosti jeho uplatňovania neboli vždy ideálne a záviseli od mnohých faktorov. Dôležitú úlohu tu zohrávalo napríklad právne vzdelanie a intelektuálne zázemie. Vidiet to na recepcii kánonického práva po tom, ako do Uhorska prichádzali prví absolventi práva na západoeurópskych univerzitách. Tí potom mohli z pozície vysokých cirkevných hodnostárov toto právo zavádzat aj do uhorskej praxe. Časový horizont presadenia sa kánonického práva ale závisel aj od množstva dalších faktorov, ako boli politické a hospodárskej pomery v štáte a pod.

Pri štúdiu postavenia cirkevných hodnostárov v nadväznosti na najstarší uhorský vývoj (11. a 12. stor.) nemôžeme opomenút ani královské zákonníky. Ide o normy svetského práva, ktorého zdrojom bol panovník, a nie Apoštolská stolica. Dominantný priestor je v nich však venovaný cirkevným záležitostiam a osobitne aj cirkevným hodnostárom, a preto ich nemôžeme opomenút (Múcska 2004, 13). Či už zákonníky prvých panovníkov Štefana I., Ladislava I., Kolomana, alebo uznesenia najstarších synod. Často sú inšpirované staršími mimouhorskými cirkevno-právnymi zbierkami (Múcska 2007, 14) a iste aj vlastnou domácou tradíciou. Ich hodnota spočíva predovšetkým v tom, že nám pomáhajú pochopit postavenie prelátov tak v cirkevnom, ako i svetskom prostredí v období, o ktorom máme minimum iných prameňov.

Zvláštne miesto patrí pápežskej listinnej produkcii, ktorá smerovala do Uhorska (Theiner 1859; Theiner 1860; Lukcsics 1931). Jej vel'ká čast̉ bola určená priamo prelátom a venovala sa ich kompetenciám, povinnostiam, sporom, cirkevno-správnym a dảlším pastoračným otázkam. K nej môžeme pripočítat aj písomnosti, ktoré vznikali z rozsiahlej činnosti pápežských legátov a nunciov, ktorí často disponovali rozsiahlymi právomocami (fakultami). Tie im umožňovali intenzívne vstupovat tak do vnútrocirkevných, ako aj celokrajinských záležitostí (Kalous 2010, 81-97). Zvláštnu skupinu prameňov tvoria nariadenia cirkevných synod, predovšetkým tých, ktoré prebiehali v kompetencii pápežských legátov a nunciov. Pápežskí vyslanci ich využívali predovšetkým ako jeden z prostriedkov, ktorými sa pokúšali reformovat vnútrocirkevné, ale i všeobecné pomery

6 Nariadenia kánonicko-právnych zbierok a koncilov sa v mnohom opakujú, resp. novelizujú. Pre prehladnost̉ budem v rámci tohto príspevku vychádzat prevažne z prehladných koncilových nariadení. $\mathrm{V}$ príslušnej literatúre, na ktorú odkazujem, sú s dalšími normami (prameňmi) komparované a je lahké ich $\mathrm{v}$ prípade potreby dohladat. 
v královstve. Na zvolaných synodách boli za účasti najvyšších cirkevných a svetských predstavitel’ov promulgované nariadenia, ktoré sa $\mathrm{v}$ praxi mohli prejavit' len za účinnej snahy zainteresovaných. Mnohé z nich sa dotýkali práve najvyšších hodnostárov. ${ }^{7}$

Reálnu implementáciu kánonického práva v otázkach jurisdikcie cirkevných hodnostárov možno sledovat predovšetkým prostredníctvom listinných prameňov, ktoré vznikali $\mathrm{z}$ ich vlastnej činnosti. V Uhorsku sa spísomňovanie právnych aktov vykonávaných prelátmi začína v malej miere objavovat v 12. storočí (Marsina 1990, 16-17). K ich rozšíreniu došlo najmä v 13. storočí. Tu však nešlo o písomnosti vydávané v rámci vlastnej jurisdikcie biskupa, ale o verejno-notárske dokumenty vydávané z nariadenia krála (Marsina 1989, 98). Rozsah písomnej agendy sa postupne výrazne zväčšoval (Lehotská 1972, 330). Dôkladnou analýzou týchto písomností, či už ide o riešenú problematiku, alebo použité postupy, rozhodnutia a pod. nám pomáhajú osvetlit', ako v praxi právomoci biskupov vyzerali a ako s nimi narábali. Vždy je ale potrebné dôsledne sledovat', či išlo o rozhodnutie vyplývajúce zo zvrchovanej moci preláta. Často sa stretneme s tým, že išlo o splnenie príkazu nadriadenej cirkevnej inštancie (napr. metropolitu sufragánnemu biskupovi), Svätej stolice (ktorý mohol byt reprezentovaný pápežským legátom) alebo svetskej moci.

\section{Kánonický postup pri obsadzovaní biskupských stolcov}

Jedným z najdôležitejších predpokladov plnohodnotného vykonávania biskupskej služby bolo legitímne obsadenie biskupského stolca. Minimálne v teoretickej rovine mohol byt skutočným nositelom všetkých foriem moci vo svojej diecéze len riadne inštalovaný biskup. Pravidlá a postupy, ktoré priebeh obsadenia stolca určovali sa v období stredoveku pomerne dynamicky vyvíjali a prirodzene podliehali zmenám. V období budovania ranostredovekého Uhorského královstva intenzívne do tejto oblasti vstupovali panovníci. V súlade so všeobecnými zvyklostami zriad’ovali biskupstvá a dosadzovali biskupov. Nemohli však postupovat úplne autonómne. O kreovaní biskupstiev hovorí Väčšia legenda sv. Štefana, že prebehlo „s písomným súhlasom nástupcu apoštolov na rímskom stolci“ (Marsina 1997, 53), resp. zakladacia listina Pätkostolského biskupstva (1009) hovorí, že biskupstvo vzniklo „so súhlasom svätej stolice, a v pritomnosti jej vyslanca biskupa Azona" (CDH I 1829, 291-292). O obsadení ostrihomského stolca spomenutá legenda hovorí, že prebehlo „kánonickou volbou“. Nemožno ale pochybovat o tom, že panovníkov vplyv na výber biskupa bol velký.

Ďalšie obdobie bolo už silne poznačené bojom o investitúru biskupov, ktorý sa naplno rozhorel počas pontifikátu pápeža Gregora VII. Napriek silnému odporu panovníkov a svetskej moci proti zákazu menovania biskupov svetskými autoritami, môžeme vidiet’ snahy panovníkov vlastné počínanie legitimizovat. Taká je napríklad teória o apoštolskej legácii Štefana I., ktorej chýba akákolvek opora v práve a vznikla zrejme na dvore krála Kolomana práve v kontexte boja o investitúru (Tomko 1995, 25-30; Múcska 2004, 58-61; Chaloupecký 1928, 32).

Dôležitú úpravu predstavuje nariadenie Druhého lateránskeho koncilu (1139), ktorý jasnejšie definoval, kto mohol volit biskupov. Mali to byt kanonici príslušnej katedrálnej kapituly.

\footnotetext{
Ako príklad nám môžu poslúžit aktivity kardinála Gentilisa. Ten sa pokúšal o nápravu neporiadkov v mnohých oblastiach uhorského verejného života výrazne poznačeného bojmi o moc na začiatku 14. storočia. Jedným z prostriedkov, ktoré využíval boli aj synody. Napríklad na tej, ktorú zvolal v 1308 do Budína sa činnosti prelátov venovali osobitne články: V. O nenapádaní prelátov; VI. O chovaní cirkevných osôb; VII.O zákaze prijímania benefícií $\mathrm{z}$ rúk laikov; IX. O magistroch v katedrálnych kostoloch; XI. O praxi zaužívanej pri volbách a XVI. O prijímaní a uverejňovaní konštitúcií na synodách na žiadost̉ krála (Marek 2012, 38-45).
} 
Z volby mali byt pod hrozbou trestu vylúčení mnísi, ktorí mali mat' len poradný hlas. ${ }^{8}$ Presnejšie bol postup legislatívne ošetrený nariadeniami Štvrtého lateránskeho koncilu (1215) (DSP II 2007, IV. LK, čl. 24.1-5, 262) a dekretáliami Gregora IX. (1227 - 1241). Volba mohla prebehnút tromi možnými spôsobmi. Prvá možnost̉ bola hlasovaním všetkých členov kapituly (per scrutinium), druhá spočívala v možnosti, že za kapitulu volili po dohode vybraní členovia (per compromisum) a tretia možnost' spočívala $\mathrm{v}$ tom, že predsedajúci volbe povedal meno kandidáta a všetci voliči

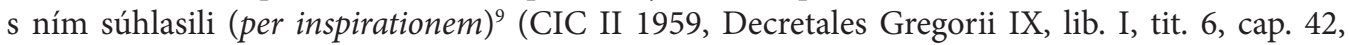
88-89). Zvolený kandidát sa mal do mesiaca vyjadrit, či vol'bu prijíma. V prípade vol'by biskupa zohrával dôležitú úlohu nadriadený arcibiskup, do ktorého jurisdikcie sufragánny biskup patril. Biskup ho musel požiadat o potvrdenie (konfirmáciu). Zvolený arcibiskup zasa žiadal o potvrdenie apoštolský stolec. Konfirmátor bol povinný dôsledne preskúmat’ zvoleného klerika, či je vhodný pre daný úrad. V prípade nedôslednosti a konfirmácie osoby, ktorá nesplńala požadované kritériá hrozili arcibiskupovi prísne tresty (DSP II 2007, IV. LK, čl. 26.1-6, 264, 266). V prípade potvrdenia získaval ako potvrdený biskup biskupskú moc in spiritualibus a in temporalibus. Konfirmácia arcibiskupa mohla prebiehat viacerými spôsobmi. Budto sa dostavil k pápežskému stolcu, kde boli určení preláti, ktorí mali záležitost̉ vyriešit', alebo mohol vyslat svojich zástupcov a v tom prípade bolo od preskúmania zvoleného arcibiskupa upustené a skúmaná bola správnost’ priebehu vol'by a spôsobilost' zvoleného priamo v mieste volby osobami, ktoré dôverne poznali situáciu v provincii (Knappek 1934, 82-84).

Po získaní konfirmácie biskup už musel pôsobit v príslušnej diecéze a nemohol sa úradu bez povolenia slobodne vzdat. Od 13. storočia dokážeme na základe prameňov diplomatickej povahy pomerne presne mapovat množstvo prípadov, ked’ do obsadzovania postu biskupa vstupovali panovníci, pápeži či další uhorskí cirkevní hodnostári. Toto vstupovanie na spôsob nátlaku, ponuky, želania atd'. však bolo mimo noriem kánonického práva.

Osobitnú rozsiahlu tému predstavujú prípady, ked’ zvolený kandidát nespĺňal nejakú kánonickú požiadavku. Bol napríklad biskupom v inej diecéze, nedosahoval predpísaný vek, bol zdravotne nespôsobilý, nemal primerané vzdelanie, vznikol spor o legitímny priebeh volby a podobne. V takom prípade cirkevné právo poznalo proces tzv. postulácie. Až po získaní dišpenzu sa takýto postulovaný kandidát mohol ujat úradu. Zatial čo konfirmácia bola bežný spôsob potvrdenia do úradu, postulácia bola udelenie dišpenzu od určitej prekážky. Pod dišpenzom tu rozumieme legálnu výnimku, udelenú podla určených pravidiel kompetentnou cirkevnou autoritou. Postulácia bola proces v podstate podobný s volbou, ale namiesto eligo (volíme) užívali pojem postulo. Podobne ako pri volbe, ak postulátori vybrali nespôsobilého kandidáta a o jeho nevhodnosti vedeli, mali byt $\mathrm{z}$ dalšej volby vylúčení v prospech tých, ktorí sa neprevinili. Ak sa previnili všetci členovia kapituly, nastala devolúcia $\mathrm{v}$ prospech pápežského stolca, ktorý sám rozhodol o obsadení stolca (Knappek 1934, 92-93).

V Uhorsku máme od 13. storočia zmapovaných viacero prípadov takéhoto procesu. Zaujímavý spor sa rozvinul v r. 1204, ked' Ostrihomská kapitula postulovala za ostrihomského arcibiskupa aktuálneho kaločského arcibiskupa Jána. Tento výber vyvolal nevôlu sufragánnych biskupov ostrihomského stolca. Členovia Ostrihomskej kapituly svoje rozhodnutie zdôvodňovali dohodou s panovníkom. Hovorili priamo o tom, že by si nedovolili zvolit niekoho, kto nemá dôveru krála.

8 „Obeuntibus sane episcopis, quoniam ultra tres menses vacare ecclesias prohibent patrum sanctiones, sub anathemate interdicimus, ne canonici de sede episcopali ab electione episcoporum excludant religiosos viros, sed eorum consilio honesta et idonea persona in episcopum eligatur. Quod si exclusis eisdem religiosis electio fuerit celebrata, quod absque eorum assensu et convenientia factum fuerit, irritum habeatur et vacuum." (DSP II 2007, II. LK, čl. XXVIII, 160).

9 V tomto prípade ide o napodobenie pápežskej volby aklamáciou. 
Sufragáni Ostrihomskej arcidiecézy ${ }^{10}$ sa obrátili na pápeža Inocenta III. a obhajovali svoj postoj argumentom, že oddávna volili ostrihomského arcibiskupa sufragáni s kapitulou (tento argument už neskôr nikdy nezaznel). Zdôvodňovali aj to, že už ako kaločský arcibiskup viackrát pôsobil proti záujmom zosnulého ostrihomského arcibiskupa Ugrina, a že by sa aj im mohol za ich predchádzajúce tvrdé postoje voči nemu pomstit. Kapitula zasa argumentovala tým, že riadne sufragánov pozvala k jednaniu, ale že tí síce prišli, ale odmietli dat súhlas (assensus) a odmietli prispiet’ radou a pomocou. Vec sa ešte výrazne komplikovala po smrti krála Imricha a po sporoch vojvodu Ondreja, tútora nedospelého krála Ladislava IV. s kaločským arcibiskupom. V konečnom dôsledku ale pápež predsa len povolil postuláciu Jána. Dodáva ale, že by bolo vhodnejšie vybrat niekoho zo sufragánnych biskupov, než arcibiskupa z inej metropoly (Knappek 1934, 94-97). ${ }^{11}$ Tento prípad ilustruje množstvo problémov, ktoré obsadzovanie postov arcibiskupov prinášalo. Či už sú to antagonistické vzt̉ahy medzi biskupmi, záujmy sufragánov, alebo zložitá situácia kapituly vo vztahu $\mathrm{k}$ panovníkovi a v neposlednom rade vstup pápežského stolca do celého procesu. Predovšetkým emancipácia pápežskej moci sa prejavovala aj v riešení otázok obsadzovania biskupstiev. Stále intenzívnejšie ho možno vnímat od 2. polovice 13. storočia a predovšetkým v 14. storočí. Pápeži čoraz častejšie obmedzovali kanonickú volbu kapitulou a sami prostredníctvom rezervácií a provízií biskupstiev začali obsadzovat nielen nižšie, ale aj najvyššie benefíciá. $\mathrm{K}$ tomu, samozrejme, treba prirátat aj zásahy známe už zo skoršieho obdobia ako konfirmácie, apelácie pri sporných vol'bách, pripúštanie postulácií, translácií a podobne. Rozlišujeme najmä generálne a špeciálne rezervácie. Prvé si pápeži vyhradzovali nezávisle od krajiny, diecézy, provincie. Išlo napríklad o prípady, ked’ prelát zomrel pri pápežskej kúrii alebo v jej blízkosti (dva dni cesty od kúrie), alebo sa uprázdnil stolec zrušením volby, transláciou biskupa na iný post. Špeciálnymi rezerváciami si pápeži vyhradzovali tieto práva jednorázovo alebo trvalo v konkrétnych diecézach. Je ale potrebné povedat', že rezervácie sa ako účinný nástroj pápežskej politiky ujímali len postupne a nedodržiavali sa vždy dôsledne (Knappek 1934, 134-135, 153). V roku 1363 si Urban V. rezervoval obsadzovanie všetkých významných cirkevných benefícií (aj arcidiecéz a diecéz) uprázdnených akýmkolvek spôsobom tak, že ich môže obsadzovat’ akokolvek bude chciet' (Knappek 1934, 138-140).

Samostatnou témou sú panovnícke zásahy do menovaní biskupov. Už vyššie som uviedol, že $\mathrm{v}$ počiatkoch formovania uhorského štátu postupovali uhorskí králi, podobne ako panovníci v dalších európskych krajinách, pomerne volne. S upevňovaním postavenia cirkvi boli tieto procesy čoraz viac zväzované cirkevným právom. Koncom 12. storočia už panovníci zväčša participovali na obsadení biskupstva tak, že dali súhlas s uskutočnením volby alebo zvolením konkrétnej osoby (Knappek 1934, 80). To ale neznamená, že do týchto otázok aktívne nevstupovali. Znamená to, že tak konali bez opory v nejakých špecifických právach, čisto z pozície ich mocenského postavenia, predovšetkým z politických záujmov.

Biskupi predstavovali popri velmožoch jednu z najdôležitejších mocenských skupín v krajine, ktoré mohli byt' účinnou oporou panovníckej moci, alebo naopak silnou opozíciou. Ked’ sa pozrieme na niekol'ko príkladov z obdobia vrcholného stredoveku, môžeme vidiet', že napríklad Karol Róbert presadzoval do čelných cirkevných úradov členov reholných rádov. Dôvody boli prozaické. Nad prelátmi pochádzajúcimi z mocných vel’možských rodov nemohol mat účinnú kontrolu a mohli predstavovat výraznú opozíciu jeho vládnutia. V prípade príslušníkov žobravých reholí bolo toto riziko menšie. ${ }^{12}$ Vo viacerých prípadoch panovník z rovnakých dôvodov presadil

10 Menovite to boli pätkostolský biskup Calan, vacovský biskup Boleslav, vesprímsky biskup Kalan a nitriansky biskup Ján (MES I 1874, s. 175, č. 165).

11 Tam pozri všetky relevantné pramene k celému priebehu sporu.

12 Príslušníkom rehole františkánov boli napríklad kaločský arcibiskup Ladislav (od r. 1317), nitriansky biskup Vít a sriemsky biskup Gregor (obaja od r. 1334). K dominikánom patrili záhrebský biskup Augustín 
aj príslušníkov vlastného či spríbuzneného rodu. Takto získal post ostrihomského arcibiskupa Boleslav (1321 - 1328) z rodu Piastovcov, brat královej prvej manželky, ako aj vojvoda Meško (1328 - 1334), ktorý sa stal nitrianskym biskupom. Karol Róbert dokonca dosadil na post rábskeho biskupa svojho nelegitímneho syna Kolomana (1337 - 1375) (Knappek 1934, 191-192; Pór 1889, 375). V prípade brata ostrihomského arcibiskupa Boleslava, Meška, bol nátlak naozaj výrazný. Na príkaz arcibiskupa ho museli zvolit nitrianski kanonici. Tí boli dokonca držaní v ostrihomskom väzení, pod vyhrážkou smrti v prípade neuposlúchnutia. V tomto prípade sa ale vdaka účinnej (najmä finančnej) pomoci zo strany panovníka podarilo Meškovi konsolidovat pomery v Nitre a vd’aka tomu aj zlepšit vzt’ahy s kapitulou (Lukačka 2011, 127).

Presadenie panovníckeho kandidáta na pápežskom dvore z času na čas narážalo aj na silnejší odpor pápežov. Asi najvýstižnejšie to ukazuje list Gregora XI. královnej matke Alžbete. Pápež stratil trpezlivost' s Ludovítom I., ktorý pri požiadavkách na obsadzovanie biskupských postov zrejme zachádzal prid’aleko. Gregor tvrdo vyčíta královi, že žiaden iný panovník nebýva pápežom tak často vypočutý ako práve Ludovít. A že nie je slušné, aby všetky dôležité cirkevné hodnosti boli obsadzované len na základe panovníkových predstáv, kedže to náleží, z plnej moci danej od Boha, len Apoštolskej stolici. Doslova píše, že také niečo si nárokujú „len tyrani a nie katolícki králi“ (Knappek 1934, 196-197). ${ }^{13}$ Ešte dalej zašiel král Žigmund Luxemburský, ktorý viacerými dekrétmi výrazne obmedzoval možnosti a práva pápežov vstupovat do uhorských cirkevných záležitostí. Ilustruje to jeho postup po tom, ako sa pápež Bonifác IX. v boji o trón zastal krála Ladislava Neapolského. Nariadením z 9. 8. 1403 zakázal pod hrozbou tažkých trestov prijímanie pápežských búl. Ďalším dekrétom zo 6. 4. 1404 si osoboval právo obsadzovat všetky cirkevné benefíciá, ktoré predtým udeloval pápež sám alebo prostredníctvom legátov (Knappek 1934, 203). ${ }^{14} \mathrm{~V}$ praxi to ale tak drastické nebolo. Hoci považoval biskupské posty obsadené jeho oponentmi za uvolnené, menoval na ne iba laických administrátorov. Prípadne siahol k osvedčenej taktike a prinútil kapitulu zvolit pre neho výhodného kandidáta. Taký prípad nastal v Nitre, kde menoval za biskupa Hynka, ktorý ale bez pápežského potvrdenia spravoval diecézu od r. 1404. Pápež povolil jeho konfirmáciu až 28. 9. 1407 (Knappek 1934, 204). Takýto priamy boj s pápežom si však neskorostredoveký panovník z dlhodobého hladiska nemohol dovolit. Minimálne v prípade, ked’ mal záujem o cisársku korunu. V roku 1410 nakoniec Žigmund výrazne ustúpil a prijal do značnej miery ponižujúci kompromis pápeža Jána XXIII. Pápež si rezervoval obsadzovanie všetkých uhorských biskupstiev, ale mal pritom brat na zretel' králových kandidátov. Napriek tomu si král a jeho nástupcovia čast’

(od r. 1303, sedmohradský biskup Benedikt (od r. 1309), bosniansky biskup Peter (od r. 1317), záhrebský biskup Jakub de Corvo (od r. 1322) a vacovský biskup Rudolf (od r. 1329) (Knappek 1934, 191-192).

13 „... quod omnia prelature dignitates et beneficia, in quibus dieta sedes meram et plenam a deo potestatem obtinet, ad beneplacita principum et aliorum dominantium concedantur. Hec enim non catholici reges sed iranni faciunt, quorum exemplum perniciosum et damnabile ipsi regi per aliquos detestabiles reges successores, ut audivimus, allegatur." (Fraknói 1892, 395).

${ }^{14}$ „... ut nullus bullatus auctoritate videlicet apostolica vel alia quavis preterquam nostra, sine nostro speciali consensu et assensu beneficia ecclesiastica curata vel non curata, cuiuscunque valoris existant, olim uti percepimus, vigore litterarum apostolicarum vel legatorum eius seu aliorum quorumcunque prelatorum acceptari et assequi et etiam tempore disturbiorum proxime preteritorum regni nostri assecuta et obtenta possidere, retinere et habere, durantibus instantibus dissensionum regni nostri temporibus et presenti decreto nostro immutato vel irrevocato per expresum, nec aliquis prelatorum eorundem et virorum ecclesiasticorum, ciuscunque statuts, ordinis, gradus, conditionis vel preeminentie existat, preter nobiles seculares ius patronatus eligendi et presentandi habentes, beneficia qualiacunque vel quomodocunque vacantia vel vacatura cuiqam providere et de eis disponere in toto vel in parte preter nostram maiestatem, cuius dispositioni, collationi et provisioni ea pleno iure reservamus..." (DRMH II 1992, 30). 
patronátnych práv ponechali (Knappek 1934, 205-206; Chaloupecký 1928, 54-55). ${ }^{15}$ V podobnom duchu potom postupoval predovšetkým král Matej Korvín. Ten v roku 1458 daroval patronátne právo nad Nitrianskym biskupstvom, ktoré si nárokoval, palatínovi Michalovi Orságovi. V tomto konkrétom prípade, $\mathrm{v}$ podstate protiprávny postup, nemal len negatívne dôsledky. Silný rod daleko lepšie dokázal čelit ambíciám okolitých rodov a mohol účinnejšie chránit aj majetky biskupstva (Lukačka 2011, 132).

Problematika obsadzovania postov arcibiskupov a biskupov predstavuje súbor zložitých otázok, ktoré nemožno vyriešit prostredníctvom niekolkých základných téz. Faktory, ktoré ovplyvňovali personálne obsadzovanie najvyšších cirkevných postov v Uhorsku sa v rozmedzí 11. až 16. storočia mnohokrát menili. Aktuálna politická situácia a stav královskej moci, rozvoj kánonického práva a pápežské stratégie, postoje cirkevnej hierarchie a vplyvných šlachtických rodov, to všetko boli faktory, ktoré zohrávali v týchto procesoch dôležitú úlohu. Pre dalšie dôkladné štúdium možno odporúčat predovšetkým, aj v rámci tejto štúdie, hojne citovanú prácu L. Knappeka o obsadzovaní uhorských biskupstiev. Autor sa v nej opiera o množstvo zachovaných dobových prameňov, ktorých prístupnosț napríklad v edíciách umožňuje d’alší dôkladný výskum.

\section{Práva a povinnosti (arci)biskupa pri správe (arci)diecézy}

„Žiadnemu archidiakonovi, archipresbiterovi, prepoštovi alebo dekanovi nemôže byt' zverená starostlivost'o duše alebo cirkevná prebenda bez rozhodnutia alebo súhlasu biskupa. Rozumie sa podla ustanovenia posvätných kánonov, že starost’o duše a všetky cirkevné záležitosti patrí rozhodnutiu a moci biskupa." (DSP II 2007, I. LK, čl. IV, 120). Toto pomerne všeobecné nariadenie Prvého lateránskeho koncilu (1123) vystihuje niektoré zo základných úloh, ktoré mal biskup na jemu zverenom teritóriu vykonávat'. Pojem „starostlivost’o duše a všetky cirkevné záležitosti“ v sebe skrýva mimoriadne široký komplex práv a povinností. Okrem toho bol biskup strážcom, ochrancom a garantom katolíckej viery a morálky, ale aj mnohých pravidiel života v súlade so svetskými zákonmi v (arci)diecéze (DSP II 2007, II. LK, čl. XII.2, 150). Súčastou toho bola povinnost' bojovat za čistotu viery s heretikmi. ${ }^{16}$ Všetky spomenuté okruhy povinností neboli a ani nemohli byt' zhrnuté v jedinom kánone. Excerpciou najrôznejších dobových noriem kánonického práva si ale možno vytvorit pomerne plastickú predstavu, čo cirkev od biskupa očakávala, a aké právomoci k vykonávaniu úloh dostal. Svetské právo nám zasa umožňuje pohlad „Zvonku“ a ukazuje, ako si miesto cirkvi a jej predstavitelov v spoločnosti predstavovala vládnuca svetská moc. Tieto normy sa v ranostredovekej Európe formovali a presadzovali len postupne. Išli ruka v ruke s vývojom predstáv o tom, ako majú najvyšší cirkevní hodnostári svoj úrad vykonávat', ktoré autority, a akým spôsobom majú ich konanie regulovat'. Na nasledujúcich riadkoch si predstavíme najvýznamnejšie práva a povinnosti biskupov tak, ako ich odzrkadluje uhorské cirkevné zákonodarstvo 11. až 14. storočia.

15 „Proinde statuimus, ut nullus omnio clericorum seu religiosorum virorum absque presentatione et nominatione regis vel nostra aliquam ecclesiam kathedralem vel quodcunque beneficium ecclesiasticus sibi per sedem apostolicam conferri et se in eisdem confirmari facere, ac etiam aliquem regnicolarum ad curiam Romanam seu extra hoc regnum, nisi per viam appellationis citare audeat." (DRMH II 1992, čl. XXIII, 120).

16 Ak by biskup v týchto povinnostiach zaujal benevolentný prístup, mal byt zosadený zo svojho úradu: „Si quis enim episcopus super expurgando de sua dioecesi haereticae pravitatis fermento, negligens fuerit vel remissus, cum id certis indiciis apparuerit, et ab episcopali officio deponatur et in loco ipsius alter substituatur idoneus, qui velit et possit haereticam confundere pravitatem." (DSP II 2007, IV. LK, čl. 3.13, 234). 


\section{Cirkevné fundácie a ich zabezpečenie}

V listine ostrihomského arcibiskupa Čanáda z 23. 4. 1337, ktorou obnovoval fungovanie Ostrihomskej kapituly sv. Juraja sa píše: „Equitas suadet canonica, quod pastorali officio necessario incumbat, ut suarum ecclesiarum status studiose, mente solerti velit procurare, et si detrimentum pati videatur, benigno suffragio conetur reformare, reformatumque pio proteccionis affectu inconcussum desideret conservare." (MES III 1924, č. 421, 294). Táto výstižná „poučka“ - arenga listiny nám podáva informáciu o tom, $\mathrm{v}$ čom spočívali povinnosti biskupa pri starostlivosti o cirkevné fundácie. Platí to pre tie najvýznamnejšie inštitúcie, ako boli kapituly kanonikov, ako aj radové farnosti či malé kaplnky, stojace na najnižšom stupni cirkevnej správy. Základnou podmienkou existencie funkčnej pastorácie bola fyzická existencia sakrálnych objektov (kostolov, kaplniek, cintorínov). Len v sakrálnych, posvätených priestoroch mohla byt’ vysluhovaná väčšina liturgických úkonov (sviatostí) veriacim a len $\mathrm{v}$ nich mohli pravidelne navštevovat bohoslužby predovšetkým $\mathrm{v}$ nedele a sviatky.

Sakrálne objekty však nemohli fungovat len samé o sebe. Museli byt primerane zabezpečené majetkami a príjmami. ${ }^{17}$ Čiže museli mat to, čo kánonické právo nazýva fundácia. To umožňovalo ich bezproblémový chod, vybavenie inventárom nevyhnutným pre potreby liturgie, opravy a rekonštrukcie. Okrem toho z nich museli byt vydržiavaní klerici, ktorí tu vykonávali pastoračnú službu. Či už to boli farári vo farnostiach, kanonici pri kapitulných chrámoch, a okrem toho početné zástupy vikárov, kaplánov, rektorov, oltárnikov atd'. Vzhl’adom na štruktúru a fungovanie stredovekej spoločnosti bol vznik a zabezpečenie týchto inštitúcií vo výraznej miere závislý od svetského patróna. Cirkev spravidla nedisponovala takými prostriedkami, aby dokázala spomenuté potreby zabezpečit sama. O čím väčšiu fundáciu išlo, tým väčšie prostriedky si jej konštituovanie a chod vyžadovali. Najvýznamnejšie z nich, ako boli biskupstvá, kapituly či vel'ká opátstva zakladal panovník, následne vel’moži (napr. kláštory) až po menších zemepánov, ktorí fundovali farské a filiálne kostoly či kaplnky. Toto intenzívne previazanie fundácií so záujmami a predstavami svetských patrónov prinášalo mnohé problémy, ktorým bola venovaná intenzívna pozornost'.

Emancipácia cirkvi, ktorá v 11. a 12. storočí naberala nový rozmer znamenala snahu postupne zatláčat vplyv svetských osôb a naopak posilňovat postavenie cirkevných autorít. ${ }^{18}$ Svetský fundátor nemohol slobodne disponovat’ majetkom kostola, ktorý mu určil. V priebehu 13. storočia sa ujala doktrína, podla ktorej laik nemohol darovat kostol. To prináležalo len biskupovi, ktorý $\mathrm{k}$ tomu ale mohol dat' súhlas (Meliš 2016, 24-47).

Aby nová farnost', kostol, kaplnka či cintorín mohli vôbec vzniknút, musel takúto aktivitu fundátorovi povolit diecézny biskup, pod ktorého cirkevnú jurisdikciu príslušné územie patrilo. Právo vysvätit nový sakrálny objekt prináležalo vždy diecéznemu biskupovi. Stretneme sa ale aj so situáciami, ked’ tento slávnostný liturgický akt povolil vykonat biskupovi z inej diecézy. Na žiadost’ spišského prepošta Gašpara Baka takto povolil ostrihomský arcibiskup Ján vysvätenie kaplnky v prepoštskej kúrii jágerskému biskupovi, ktorý bol jeho sufragánom, alebo inému biskupovi,

17 Už ustanovenie Prvej ostrihomskej synody (1105 - 1116 ?) prikazovalo, že bez takéhoto zabezpečenia nemá byt' kostol ani vysvätený (Marek 2010, 135).

18 Volnej manipulácii s cirkevnou fundáciou malo zabránit napríklad nariadenie Prvého lateránskeho koncilu (1123): „Decimas et ecclesias a laicis non suscipiant absque consensu et voluntate episcoporum et si aliter praesmptum fuerit, canonicae ultioni subiaceant." (DSP II 2007, I. LK, čl. XVIII, 130). Podobné nariadenia opakuje aj II. Lateránsky koncil (1139): „Decimas ecclesiarum, quas in usu pietatis concessas esse canonica demonstrat auctoritas, a laicis possideri apostolica auctoritate prohibemus. Sive enim ab episcopis vel regibus vel quibuslibet personis eas acceperint, nisi ecclesiae reddiderint, sciant se sacrilegii crimen committere et periculum aeternae damnationis incurrere." (DSP II 2007, II. LK, čl. X.1, 148). 
ktorého prepošt uprednostní. ${ }^{19}$ Diecézny biskup tiež určoval, aké liturgické úkony budú môct' byt' v objekte vykonávané, a v akom vzţahu (podriadenosti, nadriadenosti) voči iným cirkevno-správnymi inštitúciám bude novovzniknutá inštitúcia figurovat. ${ }^{20}$

Agenda súvisiaca s majetkovými záležitostami a správou benefícií patrí medzi najpočetnejšiu skupinu písomností, s ktorými sa môžeme stretnút. Biskupi rozhodovali o výmenách, predaji alebo darovaní majetkov a príjmov patriacich biskupstvu. ${ }^{21}$ Zároveň potvrdzoval, obnovoval a doplńal najrôznejšie výsady, ktoré udelovali cirkevným inštitúciám či už jeho predchodcovia, ${ }^{22}$ alebo iné osoby. ${ }^{23}$ Potvrdzoval tiež mnohé dohody medzi cirkevnými inštitúciami a osobami, týkajúce sa majetkov, príjmov, výsad či kompetencií. ${ }^{24}$ Biskup často priamo ovplyvňoval manipuláciu s príjmami farností, predovšetkým s vyberanými cirkevnými desiatkami. Tie predstavujú jednu z najčastejšie riešených záležitostí, ktorú môžeme v písomnej agende sledovat. Nie je to nič prekvapujúce, ked’ vezmeme do úvahy, že cirkevný desiatok patril k najdôležitejším súčastiam príjmu farára, biskupa

19 Listina ostrihomského arcibiskupa Jána z 26. 4. 1466: „Ut liceat tibi capellam, in curia prepositurae tuae fundatam, per suffraganeum ecclesiae Agriensis, aut alium, quem malueris, antistitem catholicum facere consecrari, tibi et ill suffraganeo, aut antistiti catholico, quem elegeris, si et in quantum ipsa capella tecto, et ostiis bene munita est, tenore presentium concedimus potestatis facultatem." (Wagner 1774, č. XXXIV, 342 ).

20 Napríklad ostrihomský arcibiskup Tomáš listinou zo 4. 12. 1307 povolil miestnym šlachticom stavbu kaplnky v Malých Bučanoch. Určil ale presne, aké liturgické úkony sa v nej mohli vykonávat a aj obmedzenia, ktoré sa na ňu vztahovali: „Unde nos prout ex officio et cura pastorali paternali divinitus nobis commissis incumbit, volentes praecavere dispendia animarum gregis nobis concrediti ut teneremur, ipsorum instantissimis supplicationibus annuentes admisimus, quatenus in eadem villa Kis Bucsan capellam seu oratorium honori beate Margaritae virginis aedificent ex nostra licentia et permissione pastorali, tamen sine praeiudicio matris ecclesiae sancti Georgii martiris supradictae; ita videlicet, quod in eadem capella missas et alia divina officia capellanus de eadem prope residens valeret exercere baptisteria, catechisationes, confessiones et unctiones infirmorum possint percipere ab eodem tempore necessitatis incumbente, excepta sepultura, quam matri ecclesiae supradictae mandamus praesentibus reservari..." (MES III 1924, č. 958, 709-710).

${ }^{21}$ Ostrihomský arcibiskup Čanád listinou z 26. 4. 1332 prenechal štvrtinu desiatkov z úrody Bratislavskej kapitule: „...cum universis suis iuribus et pertinendis, ac utilitatibus earumdem, de novo paternaliter duximus confirmandas et patrocinio litterarum nostrarum roborandas; committentes nostris decimatoribus, nunc pro tempore constitutis, vel in futurum constituendis, ut quartas prefatarum decimarum nostrarum, ipsum capitulum tangentes, ipsis et eorum procuratoribus plene et integre dare et exigere permittant; qui si secus facerent in premissis, indignacionem omnipotentis Dei, beatorumque Petri et Pauli apostolorum, necnon beatissimi Adalberti martiris, (patroni) nostri, incurrant eo facto." (MES III 1924, č. 306, 208).

22 Ostrihomský arcibiskup Boleslav listinou z 1. 10. 1322 na žiadost’ spišského prepošta Henricha potvrdil staršie výsady, ktoré dal kňazom Toryského vicearchidiakonátu jeho predchodca arcibiskup Tomáš: „Nos itaque iustis petitionibus predicti domini Henrici prepoisti inclinati, literas supra factorum plebanum, et sacerdotum de Tharcza nobis exhibitas, ratas habemus, et approbamus, et per singulos articulos authoritate presentium confirmamus, et tenorem earum presentibus de verbo ad verbum inseri feciumus. Nulli ergo hominum liceat hanc nostrae confirmationis paginam infringere, vel ei contraire. Si quis autem ausu temerario contravenerit, excommunicationis sententiam, ex nunc per nos latam in his scriptis, se noverit incursurum." (Wagner 1774, č. XIV, 312).

${ }^{23}$ Ostrihomský arcibiskup Tomáš listinou z 19. 11. 1311 potvrdzuje staršie majetkové práva, ktorými bol obdarovaný kostol v Markušovciach prepoštom Jakubom: „Ad universorum noticiam harum serie volumus pervenire, quod ad nostram accedens presenciam magister Stephanus, canonicus ecclesie sancti Martini et plebanus beati Michaelis archangeli de Scypus, exhibuit nobis quoddam privilegium discreti viri, magistri Jacobi, quondam prepositi de Scypus, petens nos cum instancia, ut idem ratum habere et nostro dignaremur privilegio confirmare." (MES II 1882, č. 653, 729).

24 Napríklad listinou z 27. 4.1448 ostrihomský arcibiskup potvrdil jedenást článkov dohody, ktorými boli ukončené spory medzi spišským prepoštom a Spišskou kapitulou (Feňarová 1964, č. 328, 96). 
a dalších osôb. Jeho vyberanie priamo podliehalo biskupovi, ktorý túto činnost' delegoval na svojich podriadených (Kušík 1961, 462-464; Oslanský 1987, 361-370; Šotník 2001, 48-57).

Popri materiálnom zabezpečení bolo dalšou podmienkou funkčnosti cirkevnej fundácie jej personálne zabezpečenie. Aj v tejto oblasti sa postupne právomoci biskupa rozširovali. Nariadenia spomenutých lateránskych koncilov hovoria o tom, že v prípade menších benefícií, najmä farností, mal byt farár prezentovaný pred biskupom (ius inveniendi sacerdotem). Všeobecne ale právomoci biskupa v personálnych otázkach pri obsadzovaní benefícií klerikmi boli v stredoveku aj $\mathrm{v}$ ranom novoveku pomerne obmedzené. I po presadení biskupského potvrdenia predstavoval určujúci faktor patrón inštitúcie (Šotola 2007 , 327-328).

V priebehu 12. a 13. storočia môžeme sledovat niekol'ko fáz obsadzovania farských benefícií. V prvej fáze bol (svetským či cirkevným patrónom) navrhnutý kandidát (presentatio), následne bolo ohlásené jeho navrhnutie pri novom benefíciu (proclamatio). Nasledovala fáza, v ktorej ho musel schválit a potvrdit diecézny biskup (investitura). Nakoniec bol fyzicky uvedený do úradu (benefícia) a v závere fyzické uvedenie k benefíciu (introductio) (Hrdina 2009, 348; Elbel 2007, 96). Ako príklad nám môže poslúžit proces obsadenia postu spišského prepošta z roku 1464 . Nomináciu (vymenovanie) a prezentáciu (predstavenie) prepošta vykonal svetský patrón, ktorým bol panovník. Ostrihomský arcibiskup vykonal jeho inštitúciu (ustanovenie) a konfirmáciu (potvrdenie). Samotný akt sa uskutočnil položením biretu na prepoštovu hlavu, nasledovala prísaha vernosti, poslušnosti a úcty voči arcibiskupovi a jeho nástupcom do jeho rúk a predpísanou prísahou na Evanjeliá. ${ }^{25}$

Schváleniu biskupom podliehalo aj obsadzovanie rozsahom najmenších cirkevných benefícií, ako boli napríklad hradné kaplnky patriace šlachticom. K biskupovej právomoci pochopitel’ne náležalo aj zriadenie takejto kaplnky a schválenie príslušného majetkového zabezpečenia (Hlavačková 2017, 118). V prípade niektorých mestských komunít sa od 1. polovice 13. storočia (Trnava 1238) začíname stretávat aj s královskými privilégiami oprávňujúcimi slobodne si volit farára. Povinnostou meštanov ale opät bolo predstavit ho biskupovi, ktorý musel farára v úrade potvrdit' (Meliš 2016, 24-47). ${ }^{26} \mathrm{~S}$ rozvojom pápežskej autority a moci v západnom krestanstve sa zväčšoval aj počet benefícií, ktorých personálne obsadzovanie bolo rezervované priamo pápežskej stolici. Medzi také patrili napríklad prepoštstvá a kanonické prebendy v kapitulách. Svedectvom o tom sú mnohé žiadosti pochádzajúce od uhorských svetských a cirkevných hodnostárov v pápežských suplikačných registroch zo 14. a 15. storočia (napr. Rábik 2009).

\section{Najvyšší dozor nad klerikmi v diecéze}

Z titulu hlavného predstavitela zverenej diecézy mal biskup aj najvyšší dozor a zodpovednost’ nad klerikmi, ktorí pôsobili, resp. mali pôsobit na jej území. V prvom rade jeho kontrole podliehal výber kandidátov, ktorí mali získat svätenie a pôsobit’ v diecéze. Podla kánonického práva bolo jeho povinnostou udelovat’ svätenia a cirkevné hodnosti len vhodným osobám, ktoré zodpovedali

25 „... tanquam personam bene meritam ad nominationem et presentationem serenissimi principis, et domini Mathie regis per te nobis in specie exhibitas, legitime constitit, in prefatam preposituram sancti Martini de dicta Scepus, autoritate nostra ordinaria instituimus, et confirmamus per presentes investiendo te per bireti capiti tuo impositionem presentialiter, ac plenam curam, et omnimodam administrationem iurium tam spiritualium, quam corporalium eiusdem prepositure tibi plenarie committentes; recepto tamen prius a te Caspare corporali iuramento, ad sancta Dei evangelia in manibus nostris prestito de fidelitate, obedientia, et reverentia nobis, successoribusque nostri..." (Wagner 1774, č. XXXIII, 340-341).

26 „Ut plebanum de communi eligant voluntate, qui per ipsos venerabili patri archiepiscopo Strigoniensi presentabitur in ipsorum ecclesiam confirmandus." (RDSL II 1987, č. 491, 341). 
kánonickým požiadavkám. Inak mu hrozili cirkevné tresty. ${ }^{27}$ Biskup bol povinný budto sám, alebo prostredníctvom iných vhodných spolupracovníkov dostatočne poučit svätencov o tom, ako majú vykonávat' bohoslužby a udel'ovat sviatosti. V prípade, že sa opováži svätit nepripravených kandidátov, mal byt potrestaný prísnym trestom. Odvolávajúc sa na evanjeliá články Štvrtého lateránskeho koncilu doslova hovoria: „je lepšie mat málo dobrých, ako vel’a zlých spolupracovníkov“.28

Jednou z dôležitých požiadaviek bolo to, aby klerik, ktorý mal prijat diakonské, alebo kňazské svätenie mal zabezpečené budúce benefícium, ktoré mu poskytne živobytie. Ak by ho biskup vysvätil bez splnenia tejto požiadavky, bol povinný vykrývat tieto potreby tak dlho, pokial' nezíska miesto pri nejakom kostole. Týkalo sa to klerikov, ktorí nemali vlastné prostriedky (majetok zdedený po otcovi) (DSP II 2007, III. LK, čl. V, 174).

Farári mali byt' ustanovovaní výlučne príslušným biskupom a jemu sa mali zodpovedat za veriacich farnosti (DSP II 2007, I. LK, čl. XVIII, 130). ${ }^{29}$ Preláti mali vykonávat’ dohlad nad klerikmi, korigovat prípadné chyby a reformovat ich mravy (DSP II 2007, IV. LK, čl. 7.1-4, 238, 240). Podla nariadení Druhého lateránskeho koncilu bolo povinnostou biskupa dohliadat na to, aby sa klerici správali dôstojne. Či už išlo o ich duchovný život, ale aj o zovňajšok. Mali sa vyhýbat zbytočne honosnému (napr. príliš pestrému) oblečeniu, nosit tonzúru atd'. V prípade, že ich správanie nezodpovedalo duchovnému stavu, mal ich biskup napomenút a v prípade, že nedošlo k náprave, mali stratit’ svoje benefíciá (DSP II 2007, II. LK, čl. IV, 142, 144). Už som vyššie spomenul problematiku obsadzovania farských benefícií. Kňaz, ktorý by prijal správu kostola alebo desiatky od svetskej osoby, mal byt potrestaný stratou úradu a hodnosti (DSP II 2007, I. LK, čl. XVIII, 130; III. LK, č. XIV.3, 188).

Dôležitým nástrojom biskupského dohladu nad klérom, laikmi, a komplexne farnostami v diecéze boli kanonické vizitácie. Tie vykonával budto osobne, alebo prostredníctvom poverenej osoby. Tou mohol byt biskupov vikár alebo príslušný archidiakon a dalšie prizvané osoby. Hoci nemožno pochybovat’ o tom, že kanonické vizitácie sa skutočne vykonávali, prameňov pre ich poznanie máme pre stredoveké Uhorsko pomerne málo. Dodnes zachované sú len texty vizitácie Ostrihomskej arcidiecézy z r. 1397 a drobné zmienky o niekolkých d’alších stredovekých vizitáciách (Lopatková 2014, 26; Olejník 2015, 37). V podstatne väčšej miere ich vieme skúmat̉ až v období po Tridentskom koncile, ktorý ich rázne nariadil ako výkon biskupskej moci. ${ }^{30} \mathrm{Od} 2$. polovice 16. storočia sa stali jedným zo základných prostriedkov dohladu nad farským klérom a farnostami. Dodnes predstavujú mimoriadne dôležitý prameň pre poznanie personálneho stavu a majetkového zabezpečenia a mnohých d’alších aspektov života farností (Hišem - Fedorčák, 2007; Olejník 2015, 14-38, Šimončič - Karabová 2015, 7).

Biskupi mali povinnost’ dozoru nielen nad „vlastnými“ klerikmi v diecéznej pastorácii, ale aj nad reholníkmi v kláštoroch na území svojho biskupstva. Podielali sa napríklad na udelovaní trestov mníchom, ktorí porušili niektoré pravidlá, ale zasahovali aj do pastoračných otázok. Nariadenie Prvého lateránskeho koncilu vymenúva niektoré činnosti, ako navštevovanie chorých spojené s udelovaním pomazania a spovedou, ako aj pastoráciu pri kostoloch, ktoré náležali len kňazom,

27 „Episcopi quoque tales ad sacros ordines et ecclesiasticas dignitates promovere porcurent, qui commissum sibi officium digne valeant adimplere, si et ipsi canonicam cupint efugere ultionem." (DSP II 2007, IV. LK, čl. 26.3, 264).

28 Porovnaj: Lk 6,39; Mt 15,14. (DSP II 2007, IV. LK, čl. 27.1-2, 266).

29 V uhorskej praxi sa potom stretávame s tým, že fyzické uvedenie do úradu vykonávali biskupom poverené osoby, či už jeho vikári, archidiakoni a pod.

30 „Patriarchae, primates, metropolitani, et episcopi propriam dioecesim per se ipsos, aut, si legitime impediti fuerint, per suum generalem vicarium, aut visitatorem, si quotannis totam, propter eius latitudinem, visitare non poterunt, saltem maiorem eius patrem, ita tamen ut toto biennio per se, vel visitatorres suo compleatur, visitare non praetermittant." (HRDINA 2015, hl. 3, 24. zasadanie, 2018). 
ktorí boli poverení biskupom a nie predstavitelom kláštorov (DSP II 2007, I. LK, čl. XVIa, 130). O tom, že kompetenčné otázky medzi biskupmi a opátmi boli problematické dlhodobo hovoria aj nariadenia Štvrtého lateránskeho koncilu. Snahy niektorých opátov uzurpovat si práva náležiace biskupom, ako bolo riešenie manželských káuz, udelovanie verejného pokánia (trestov) a udelovanie odpustkových listín, malo spôsobovat oslabovanie autority biskupov. Opátom sa vykonávanie týchto činnosti povolovalo len v prípade, že na to dostali špeciálne povolenie (DSP II 2007, IV. LK, čl. 60.1-2, 302). Biskupi boli zároveň povinní starat’ sa o riadny chod kláštorov a chránit ich pred akýmikolvek zásahmi svetských osôb, ktoré by narušovali ich práva. Zároveň bolo povinnostou biskupa v spolupráci s vizitátormi kláštorov riešit nápravu prípadných nedostatkov (DSP II 2007, IV. LK, čl. 12.1-7, 248, 250). Niektoré ustanovenia sú naozaj detailné. Biskupi, opáti a priori boli napríklad zodpovední aj za to, že mnísi a reholní kanonici nebudú študovat medicínu a svetské právo (DSP II 2007, II. LK, čl. IX, 146, 148).

Dôležité je konfrontovat nariadenia kánonického práva aj s uhorskými domácimi zákonmi dotýkajúcimi sa vztahu uhorských biskupov a kláštorov. O vizitačných povinnostiach biskupov v kláštoroch nás informujú už nariadenia Sabolčskej synody z roku 1092 (Múcska 2004, 85). ${ }^{31}$ Hoci boli kláštory v mnohých oblastiach vo vztahu k diecéznemu biskupovi autonómne, museli zároveň rešpektovat jeho najvyššiu autoritu ako „učitela a pastiera cirkvi“. Nariadenie synody popisuje právo biskupa (a krála) vstupovat do klauzúrnych priestorov kláštora aj povinnosti opáta a mníchov privítat biskupa bozkom pokoja (Múcska 2004, 86). ${ }^{32}$ Prisvojovanie si rôznych privilégií opátmi, ako sme to videli vyššie, riešilo aj uhorské právo. Kánony Ostrihomskej synody, ktorá sa uskutočnila niekedy medzi rokmi 1105 až 1116, napríklad zakazovali opátom používat biskupské insígnie, ako aj krstit’, spovedat’ a kázat’ veriacim (Múcska 2004, 87). ${ }^{33}$ Opáti tiež nesmeli opúštat svoje kláštory bez vedomia svojich biskupov a ak odchádzali, nemali sa zdržiavat' mimo nich príliš dlho (Múcska 2004, 87). ${ }^{34}$ Na druhej strane ustanovovat mnícha v kláštore mohol len vlastný opát, nikdy nie biskup alebo kňaz (Múcska 2004, 87). ${ }^{35}$ Tieto a mnohé dảš̌ie ustanovenia pochopitelne podliehali zmenám $\mathrm{v}$ závislosti od toho, ako sa menili kompetencie biskupov a opátov kodifikované vo všeobecných normách kánonického práva. Spomenuté nariadenia konzervujú stav v Uhorsku na prelome 11. a 12. storočia.

${ }_{31}$ „Abbates secundum decreta patrum in procuratione episcoporum suorum, in quorum territorio sunt, humiliter permaneant. Et non semel in anno, sed sepe monasteria eorum episcopi visitent et regulariter vitam et conversationem fratrum discutiant. Conversi monarchi, cui monasterio monachorum voluerint, se cum rebus suis commendent; similiter et monache in monsterio monachorum. Deinceps autem aliquis episcopus aut abbas sine titulo certi loci monachum aut monacham non audeat ordinare." (DRMH I 1999, SabS, čl. XXI, 56).

32 „Si contigerit regi aut episcopo ad quamlibet abbatiam venire, abbas vel monachi ad regis vel episcopi osculum in ecclesia non accedant, sed egressi in claustrum, ordinatim stantes, regis vel episcopi osculum prestolentur. Regem autem et episcopum, cum quot et qualibus sibi placuerit, abbas claustrum intrare permittat." (DRMH I 1999, SabS, čl. XXXV, 58).

33 „Abbates mitram, sandalia, cirothecas, nolam ad capellam vel cetera episcopalia insignia non habeant, neque baptizent, neque penitentiam dent, neque ad populum sermonem faciant." (DRMH I 1999, OstS, čl. XXXIV, 62).

34 „Ut abbates raro de monasteriis egrediantur, neque ad regem, neque ad remotas possessiones sine conscientia episcopi pergant, ubi tamen diutius immorari non debent." (DRMH I 1999, OstS, č. XXXVI, 62).

35 „Nullus episcopus aut presbiter monachum ordinet.“ (DRMH I 1999, OstS, čl. XXXVIII, 62) 


\section{Súdne právomoci biskupa}

Ked' zostaneme pri najstarších uhorských zákonníkoch, množstvo nariadení v nich sa dotýka aj súdnych právomocí biskupov. Biskup ako sudca sa v nich objavuje v dvoch rovinách. $\mathrm{V}$ prvom rade bol, v súlade s kánonickým právom, chápaný ako sudca klerikov. Ide o tzv. privilegium fori, podla ktorého mohol byt klerik súdený len biskupom, resp. jeho súdom (Múcska 2004, 67). ${ }^{36}$ V podobnom duchu sú koncipované aj články Kolomanovho zákonníka. Podla neho kaplánov biskupov a županov mohli pred súd predvolávat len biskupi a arcibiskupi (Múcska 2004, 68). ${ }^{37}$ $\mathrm{V}$ podobnom duchu bolo koncipované aj neskoršie privilégium Ondreja II. z roku 1222, kde je toto staré právo klerikov opätovne potvrdené (Marsina 2003, 102-103). ${ }^{38}$ Ak laik žaloval klerika, malo vyšetrovanie prebehnút pred biskupom alebo archipresbyterom. ${ }^{39}$ Aj nariadenia Prvej ostrihomskej synody spomínajú, že klerika-zlodeja mal súdit iba biskup, resp. archidiakon a nie svetský sudca. ${ }^{40}$

Popri súdení klerikov biskupi pôsobili aj ako sudcovia svetských osôb. Napríklad Božie súdy (ordálie), prvky svetského a nie kánonického práva, mali byt vykonávané len v sídlach biskupov alebo vo väčších prepoštstvách (Múcska 2004, 71). ${ }^{41}$ Biskup mal pôsobit ako sudca aj v prípade tažkých deliktov, ako napríklad vraždy (Múcska 2004, 74; DRMH I 1999, Col. I, čl. L, 28-29), únosov žien (DRMH I 1999, Col. I, čl. LIX, 29) alebo cudzoložstva (DRMH I 1999, Col. I, čl. LXI, 29).

Podobne ako d’alšie oblasti činnosti biskupov, boli aj ich súdne právomoci postupne zosúlad’ované s kánonickým právom tak, ako sa formovalo a vyvíjalo. Sídelný biskup bol riadnym sudcom v diecéze. $V$ súdnych a dalších povinnostiach ho od 13. a najmä 14. storočia postupne

36 „Ordo clericalis, si anserem vel gallinam, poma vel his similia furatus fuerit, scopis tantum a magistro corrigatur, sed quod furatus est, restituat; maius his si furatus fuerit, ab episcopo suo degradetur et iudicio vulgari dampnetur.“ (DRMH I 1999, Lad. II, čl. XIII, 15).

37 „Episcoporum et comitum capellani vel reliquorum, per sigillum episcopi vel archiepiscopi ad causandum cogantur." (DRMH I 1999, Col. I, čl. V, 25).

38 "Nos itaque iam dictarum ammoniti serie rationum, universis rerum dispositionibus regalem in secularibus, clericalem in spiritualibus proferentes dignitatem, omnibus in regno nostro constitutis sacerdotibus, diaconis, subdiaconis, acolitis, exorcistis, quibuslibet in sortem domini per tonsuram clericalem insignitis, tantam ac talem auctoritate regia conferimus libertatem, ut si quispiam laicorum ex hiis aliquem sive de possessorio seu de furto, seu de terris, seu quocumque alio actionis titulo presumpserit ad iudicem trahere secularem, ipse laicus eo ipso sue cause preiudi cium faciat: quia volumus et statuimus, ut nullus clericorum ante personam trahatur secularem, nec cuiquam laicorum, dum videlicet a laico impetitur, in foro secularium iudicum respondere teneatur. Sicut enim ordo rationis exigit, ut si laicus clericum de quocumque convenire voluerit, prelatus ordini clericatus deputatis archiepiscopis, episcopis, prepositis, archidiaconis seu decanis, vel quibuslibet aliis ecclesiasticis indicibus, sue cause proponat seriem et coram eis exequatur. Similiter volumus, ac si quispiam clericorum cum laico de causis secularibus voluerit agere, coram seculari iudice conveniat, et sicut clericalem decet honestatem, habito debite cautionis moderamine, ius suum in foro iudicum secularium exequatm. Si enim persona clericalis a laico ad iudices seoulares traheretur, confusio magis quam ordo servaretur et violencia iuri pocius quam iusticia inferretur, sed utrumque providentes, sicut ordini spiritualis apicis nichil subtrahi, sic in nullo laicali dignitati; tamen in hiis, que ad forum laicale pertinent, volumus derogari." (CDSL I 1971, č, 269, 198-199).

39 „Si clericus cum laicis causam habet, per sigillum iudicis laicus cogatur; si vero laicus habet causam cum clerico, per sigillum episcopi vel archipresbiteri clericus cogatur, ab eisque coram iudice suo examinentur." (DRMH I 1999, Col. I, čl. VI, 25).

40 „Si quis clericorum furti arguitur, ab episcopo vel archidiacono iudicetur. Si reus inventus fuerit, deponatur et bona sua perdat; si nichil habuerit, vendatur." (DRMH I 1999, OstS, čl. LIX, 63)

41 „Iudicium ferri et aque in aliqua ecclesia fieri interdicimus, nisi in sede episcopali et maioribus preposituris, necnon Posonii et Nitrie." (DRMH I 1999, Col. I, čl. XXII, 26). 
začali nahrádzat zástupcovia - vikári (Labanc 2015, 67). Okrem toho treba spomenút archidiakonov. Mali právo vizitovat' farnosti, vyhlasovat’ exkomunikácie či interdikty. Tieto právomoci však boli vždy delegované a vychádzali z biskupovej súdnej právomoci. Biskup mohol farnosti podla vlastného rozhodnutia eximovat a podriadit priamo sebe. V princípe ale biskup mohol široké súdne právomoci nad klérom preniest’ aj na nižšie postavených klerikov, napríklad farárov stojacich na čele exemptných farností. V prípade náročnejších káuz mal tieto presunút priamo na biskupa. Biskup predstavoval aj odvolaciu súdnu inštanciu (Šotník 1999, 38, 42-43). ${ }^{42}$ Najmä od 14. storočia začali biskupa v súdnej funkcii nahrádzat jeho vikári (Meliš 2016, 37; Šotník 1999, 38).

Odvolacou inštanciou biskupovho súdu bol arcibiskup, resp. v prípade kaločského arcibiskupa bol vyššou odvolacu inštanciou ostrihomský arcibiskup ako prímas (od prelomu 14. a 15. storočia) a najvyššou Svätá stolica. Špecifikom kánonického práva však bolo to, že klerik mohol začat súdny spor aj na najvyššej inštancii, Svätej stolici. Spravidla boli následne pápežom delegovaní sudcovia z teritória, ktorého sa spor týkal (biskupi, opáti, kanonici atd.). Prejavom oslabovania pápežskej moci a cirkevnej moci v Uhorsku vôbec bolo najmä v 15. storočí aj postupné obmedzovanie (arci)biskupského súdnictva. Královská moc odmietala obchádzanie postupnosti súdnych inštancií a výrazná je aj snaha zamedzit rozhodovaniu cirkevných inštancií v majetkových záležitostiach (Bidovský 1976, 171-175).

Uviedli sme niekol'ko príkladov záležitostí, ktoré biskupi ako sudcovia (najmä z královskej vôle) rozhodovali v ranostredovekom Uhorsku. Pre obdobie vrcholného a neskorého stredoveku máme už k dispozícii obrovské množstvo listinných prameňov, ktoré hovoria o konkrétnych rozhodnutiach biskupov alebo ich zástupcov v súdnych záležitostiach. $\mathrm{V}$ prvom rade sa riešenia káuz a rozsudky týkali sporov medzi cirkevnými osobami navzájom. Vela z nich sa týka sporov medzi diecéznymi kňazmi ${ }^{43}$ alebo diecéznymi klerikmi a členmi reholných spoločenstiev. Arcibiskupi zároveň vykonávali súdne rozhodnutia aj v sporoch sufragánnych biskupov a d’alších osôb. ${ }^{44}$ Pomerne velkú skupinu tvoria spory týkajúce sa majetkových a hospodárskych záležitostí, príjmov, výberu cirkevných desiatkov a benefícií celkovo. ${ }^{45}$ Aktérmi týchto súdnych sporov boli biskupi, členovia kapitúl, farári, predstavitelia reholných inštitúcií atd. Ďalej sú to rôzne jurisdikčné spory medzi predstavitelmi cirkevných inštitúcií v záležitosti ich právomocí

${ }_{42}$ Listinou z r. 1290 jágerský biskup Ondrej vyňal košického farára z pod právomoci archidiakona a dáva mu aj súdne právomoci: „Concessimus edam, ut omnes causas spirituales in eadem villa emergentes rector sive sacerdos ipsius ecclesie de Cassa iudicare possit et ad quod vel ad quas ipsius pericia non sufficeret iudicandas, im hiis sit ad nos recurrendum." (Juck 1984, č. 73, 73).

43 Napríklad ostrihomský arcibiskup Boleslav listinou z 6. 8. 1322 odročil riešenie majetkového sporu medzi dvoma klerikmi na iný termín:" Nos B. Dei gracia archiepiscopus Strigoniensis eiusdemque loci comes perpetuus damus pro memória, quod quia secundum formám nostri iudicii Bartholomeus sacerdos capellanus domini regis contra Petrum sacerdotem filium Stephani assercionem suam super facto spolacionis sue, ablacione duorum equorum suorum valencium decem marcas et recepcione viginti marcarum suarum ter per nos legitime requisitus probare non assumsit, dictam causam ad octavas Epiphanie domini proxime venturas duximus prorogandam et sentencialiter discnciendam consilio saniori." (CDHA II 1881, č. 32, 41-42).

${ }_{44}$ Napríklad ostrihomský arcibiskup Vavrinec odročuje spor medzi vesprímskym biskupom Benediktom a opátom z Belae fontis ohladne cirkevných desiatkov na iný termín (MES II 1882, č. 425, 415).

45 Napríklad listina ostrihomského arcibiskupa Čanáda z 27. 11. 1335 v spore medzi Ostrihomskou kapitulou a Vesprímskym biskupom: „Et quia omnis controversie finis est iuramentum, nos ipsam particulam decimacionis vini, de qua lis et contencia orta fuerat, que Nyrmalalia vocatur, que existeret in metis possessionis KyvBoyun vocate, et coram nobis iuramento terminata, ipsi capitulo Strigoniensi sentencionaliter adiudicavimus; ipsi domino episcopo Vesprimiensi et suis successoribus episcopis, super decimis dicte partis Nyrrmalalia, a modo in futurum, perpetuum silencium imponentes; ita ut nullo unquam tempore litem de eadem valeant suscitare." (MES III 1924, č. 396, 271-272). 
a povinností. Osobitnú skupinu tvoria rozsudky nad klerikmi, ktorí porušili normy kánonického práva. Či už išlo o drobnejšie priestupky končiace miernym trestom, alebo tažké zločiny končiace napríklad exkomunikáciou. ${ }^{46}$ Poznáme aj prípady vel'kých sporov, kde bol cirkevný hodnostár obvinený zo skutočne rozsiahleho množstva porušení zákonov. Exemplárny prípad predstavuje žaloba kanonikov Bratislavskej kapituly, ktorí spísali 34 bodov žaloby voči prepoštovi. Tie sa týkali mnohých tém, ako zanedbávania liturgických povinností, disciplíny, osobných útokov na kanonikov, hospodárskych deliktov a porušovania mnohých d’alších práv kapituly a jej členov. Žalobu smerujúcu k súdnej stolici ostrihomského arcibiskupa riešili jeho delegovaní sudcovia (Lakatos $2015,161-179){ }^{47}$

Zjednodušene môžeme povedat, že biskup súdil všetky delikty klerikov podliehajúce normám kánonického práva, ale aj svetského práva. Môžeme sledovat tendenciu tieto práva prelátov postupne obmedzovat v prospech svetskej súdnej moci. Ďalšiu skupinu tvoria spory medzi klerikmi a laikmi navzájom. Pod súdnu právomoc biskupa spadali najrôznejšie záležitosti laikov, ktoré sa týkali porušovania cirkevnej disciplíny a morálky alebo narušovali cirkevné práva. ${ }^{48}$ Poznáme dokonca extrémny prípad, ked’ arcibiskup uvalil interdikt na územie celého Uhorského královstva. ${ }^{49}$ Biskupi rozhodovali aj o niektorých netrestných záležitostiach laikov. Boli to napríklad otázky dievčenskej štvrtky - vena (Lakatos - Mikó 2015, 41-43) alebo záležitosti manželského práva. ${ }^{50}$

Spomeniem ešte jednu oblast', v ktorej vystupujú biskupi v skôr pasívnej úlohe, nie priamo ako sudcovia. Preláti boli často prizývaní aj ako svedkovia závažných dohôd medzi klerikmi alebo celými cirkevnými inštitúciami. ${ }^{51}$ Vyplýva to nepochybne z toho, že najvyšší cirkevní hodnostári

46 Napríklad vesprímsky biskup Štefan listinou z 9. 9.1320 spolu so súhlasom ostrihomského arcibiskupa a ich vzájomnou zhodou exkomunikoval dvoch farárov za to, že odopreli poslušnost̉ svojmu ordinárovi: „Nos enim eorum malitiam et duritiam, ac iniuriam et damna nobis et ecclesiae nostrae illatam non valentes ex officio nostri debito ulterius conniventibus oculis pertransire, dictarum ecclesiarum sacerdotes excommunicamus et excommunicatos denunciamus publice in his scriptis." (MES III 1924, č. 966, 713).

47 V štúdii pozri podrobný rozbor celého priebehu súdneho procesu. Vzhladom na torzovitost pramenného materiálu ide o jeden $\mathrm{z}$ mála takto rekonštruovaných velkých súdnych procesov v réžii uhorských prelátov v stredoveku.

48 Napríklad listinou z 23. 9. 1343 nariadil ostrihomský arcibiskup Čanád vyšetrovanie poddaných, ktorí napadli cirkevné majetky a klerikov: „... unde cum nobis de premissis non constaret aliqua rei certitudo, devocioni vestre in virtute sancte obediencie mandamus, quatenus receptis presentibus, accedatis ad premissa inquirenda et videnda, si veritas de premissis sic se habet nec ne; et post bee scita veritate tocius ipsius inquisicionis seriem in vestris literis ad vestre consciencie puritatem nobis reseribatis; ipsosque populos salubriter ammoneatis verbo nostro, ut de premissis factis eorum usque quindenas congruam rependant satisfaccionem, qui si fecerint bene quidem, alioquin ipsis quindenis diebus transactis, auctoritate conservatoria papali contra eosdem procedemus." (CDHA IV 1884, č. 221, 370-371).

49 Takýto akt vykonal po mnohých excesoch v královstve, v r. 1232 ostrihomský arcibiskup Róbert (CDSL I 1971, č. 384, 273-275).

${ }^{50}$ Napríklad ostrihomský arcibiskup Tomáš listom z 25. 8. 1318 zrušil zásnuby: „Seribit nobis vestra paternitas, super facto desponsacionis, olim facta, inter filium Mysce, et filiam Jacobi filij Corrardi de Owar, quod scita et inquisita veritate, sicut eciam capitulum ecclesie vestre super eodem facto nobis seribit sciuissetis ueraciter, quod eo tempore, quo ille contractus füit inter eos, filia illius Jacobi nondum erat septemnis, et ille contractus per potenciám Heysce preter voluntatem parentum dicte puelle fuerat factus, et cum de iure locum non babeat consensus ubi metus vei coaccio interuenit, et illa nondum erat septempnis, et postquam ad annos discrecionis venit, si antea, tacite uel expresse prebuisset consensum, reclamauit et refutauit, potestate vestra ordinaria et nostra metropolitana, potestis dare licenciám illi puelle, nubendi, cuicumque uoluerit in domino." (CDHA I 1878, č. 433, 481-482).

51 Renovácia Zlatej buly Ondreja II. z r. 1231 priamo hovorí o tom, že pri závažnejších pokonaniach mali byt svedectvá královského poverenca - pristalda podporené ešte písomným svedectvom diecézneho biskupa, resp. kapituly (Marsina 1973, 12). 
boli zároveň jedni z najdôveryhodnejších a najakceptovanejších osôb v královstve. Ich svedectvo či garancia mala $\mathrm{v}$ dobovej spoločnosti značnú silu. $\mathrm{V}$ mnohých prípadoch túto činnosṫ vykonávali priamo, ako najvyššie cirkevné autority na danom území. ${ }^{52}$

\section{Zákonodarné právomoci biskupa}

Medzi najdôležitejšie komunikačné fóra diecézneho biskupa s príslušníkmi kléru v diecéze patrili v stredoveku synody. Uskutočňovali sa väčšinou pod vedením biskupa, ktorý ich viedol sám alebo prostredníctvom zástupcu (vikára). Synod sa zúčastňovala väčšina popredných klerikov v diecéze, počínajúc členmi kapitúl, archidiakoni, dekani, až po farárov a predstavitelov reholných spoločenstiev na území diecézy. V prípade, že išlo o synodu provinciálnu, zvolávanú metropolitom, boli jej účastníkmi preláti a d’alší vybraní klerici celej cirkevnej provincie (Krafl 2014, 55-56).

Témy prerokúvané na synode bývali rôznorodé. Ako to popisujú nariadenia Štvrtého lateránskeho koncilu, povinnostou metropolitov spolu so sufragánnymi biskupmi bolo zvolávanie provinciálnych synod. Na nich sa mali korigovat rôzne chyby a obnovovat mravy, kárat priestupky, predčítat kánonické regule, osobitne tie, ktoré boli prijaté na všeobecných konciloch a zločincom vymeriavat tresty. ${ }^{53}$ Aby bolo možné všetky tieto záležitosti riešit', mali byt v jednotlivých diecézach vybraní zodpovední klerici, ktorí mali prípadné nedostatky oznamovat svojim biskupom, resp. pripravovat o nich správy svojim ordinárom, resp. na prerokovanie dảšej synody. Synody sa mali v každej diecéze uskutočňovat každoročne, inak mal byt biskup potrestaný stratou benefícia a úradu (DSP II 2007, IV. LK, čl. 6.2-6.3, 238). Z týchto nariadení vyplýva, že na synodách sa preberali všetky závažné témy, ktoré sa dotýkali života v diecézach, predovšetkým vo vztahu k činnosti klerikov. Zároveň sa tu zoznamovali s nariadeniami cirkevných koncilov a autorít.

K právomociam biskupov patrila zákonodarná právomoc pri tvorbe vlastných partikulárnych noriem kánonického práva (Szentirmai 1961, 280-282). Biskupi ich ustanovovali pre vlastnú diecézu a metropoliti pre celú provinciu. Tieto partikulárne zákony boli najčastejšie uvádzané do praxe práve na synodách. Na synode boli verejne predčítané a prípadne prediskutované za prítomnosti väčšej časti najvýznamnejších klerikov diecézy. Velký vplyv na obsah synodálnych textov mali normy hierarchicky vyšších inštancií. Tak predstavovali základ noriem diecéznych synod výsledky ostrihomskej arcidiecéznej synody. Ten bol následne potvrdzovaný aj na viacerých diecéznych synodách (Erdő 2010, 27).

Súčastou synody ale neboli len rokovania. Jej dôležitou súčastou boli početné liturgické slávenia, ktorých sa prítomní klerici aktívne zúčastňovali. To všetko iste dávalo aj promulgácii zákonov slávnostný až sakrálny ráz. Už samotná fyzická prítomnost' klerikov na synode, prípadne možnost’ diskusie a aktívnej účasti, to všetko iste napomáhalo aj praktickej aplikácii týchto noriem v bežnej

52 Napríklad listina čanádskeho biskupa Benedikta z 19. 8. 1329, ktorou svedčil o dohode medzi vesprímskym biskupom a kapitulou na jednej strane a ostrihomskými križiakmi na strane druhej ohladne cirkevných desiatkov: „Et ut omnia premissa inconcussa permaneant et perpetuam optineant firmitatem, idem dominus episcopus et prepositus suo et eiusdem capituli nomine, predictus vero frater Jacobus, magister cruciferorum, similiter pro se et pro toto conventu suo, prestito iuramento ad manus nostras, promiserunt et obligaverunt se, ac suos successores, supradicta ordinacione et composicione firmam atque ratam perpetuo inviolabiliter observare." (MES III 1924, č. 974, 717).

53 „Sicut olim a sanctis patribus noscitur institutum, metropolitani singulis annis cum suis suffragaenis provincialia non omittant concilia celebrare, in wui de corrigendis excessibus et moribus reformandis, praesertim in clero, diligentem habeant cum Dei timore tractatum, canonicas regula set maxime quae statuta sunt in hoc generali concilio relegentes, ut eas faciant observari, debitam poenam transgressoribus infligendo." (DSP II 2007, IV. LK, čl. 6.1, 238). 
pastoračnej praxi (Labanc - Glejtek 2015, 61-62; komplexne: Kruppa - Zygner 2006). Z analýzy stredovekých synodálnych štatútov, ktoré sa nám zachovali z územia Uhorska vyplýva, že šírka tém bola skutočne vel'ká. V prvom rade sa v nich odrážajú rôzne normy univerzálneho kánonického práva. Máme tak možnost̉ sledovat', ako boli postupne implementované v uhorskom prostredí. Okrem toho synodálne sa štatúty zaoberali aktuálnymi problémami, ktoré bolo potrebné riešit na úrovni diecézy alebo provincie. Tieto témy môžeme rozdelit do niekolkých okruhov. Vel'ká skupina sa zaoberala problematikou súkromného života, odievania, dodržiavania celibátu, nevhodným svetským správaním (návštevy krčiem, vztah k ženám, používanie zbraní) a trestami pri nedodržiavaní pravidiel, ale aj testamentmi a narábaním s majetkom. S tým úzko súvisia nariadenia týkajúce sa pastoračných povinností kňazov vo farnostiach a otázky ich rezidovania pri benefíciách. Sú to inštrukcie ohladne starostlivosti o kostoly a ich vybavenia (bohoslužobné predmety, liturgické knihy a pod.). Ďalej nariadenie o slúžení svätých omší a vysluhovania sviatostí. Kňazi boli zodpovední aj za život zverených laikov tak, aby sa správali podla noriem katolíckej morálky a kánonického práva. Štatúty sa venujú postupu farárov pri udelovaní rozhrešení a trestov farníkom za ich nedodržiavanie či správnemu prístupu k exkomunikovaným osobám. Vela priestoru je venovaného otázkam obsadzovania farských benefícií laickými fundátormi bez povolenia biskupov, ktoré, ako som už vyššie spomenul, predstavovalo závažný problém. Spomínajú sa tresty a zákroky cirkevných autorít voči svetským osobám, ale i klerikom, ktorí benefícium prijali. Široké spektrum nariadení rieši aj práva a kompetencie cirkevných autorít vo vztahu k podriadeným klerikom, vztahmi k Apoštolskej stolici a pápežským legátom a podobne. Synodálne nariadenia regulovali aj množstvo otázok liturgie, ako boli napríklad partikulárny liturgický kalendár, predpísané svätenie sviatkov, slávnostné bohoslužby a modlitby. Okrem toho sa venujú v samostatných nariadeniach aj životom reholníkov v kláštoroch a príslušníkom žobravých reholí (Erdő 2005, 74-79; Erdő 1993, 617-622; Péterffy 1741; Malovecká 2006, 197-206). Závery synod ako prostriedky biskupského zákonodarstva predstavujú skutočne mimoriadne bohatú problematiku. Zachytávajú tie otázky života, ktoré v období uskutočnenia synody v spoločnosti rezonovali. Z toho dôvodu kladú dôraz na často rozdielne otázky v závislosti od obdobia zvolania, ako aj teritória, ktorého sa týkali.

\section{Udel'ovanie a schval'ovanie privilégií, práv a štatútov biskupmi}

Medzi najvýznamnejšie kompetencie ranostredovekých diecéznych biskupov nepochybne patrili kanonizačné procesy a menovania nových svätcov. V prípade uhorských dynastických svätcov sv. Štefana a sv. Imricha tak učinil ostrihomský arcibiskup so súhlasom Apoštolskej stolice. Obaja Arpádovci sa stali celouhorskými svätcami. Podla R. Marsinu bola odlišná situácia v prípade sv. Ondreja-Svorada a Benedikta, ktorí boli kanonizovaní len lokálne, zrejme svätiacim biskupom sídliacim v Nitre a ich úcta mala len územne obmedzený charakter v Nitre (Marsina 2010, 23-24). Zvláštny záujem na tomto kanonizačnom procese mal iste nitriansky vojvoda Gejza. Mat' „vlastných" svätcov so strediskom kultu priamo na spravovanom území bola nepochybne aj záležitost’ prestíže (Ruttkay 2016, 8). Prejavom nárastu pápežskej moci a univerzálneho postavenia pápeža v západnom krestanstve bola aj postupná tendencia podriad’ovat priebeh kanonizácie výlučne pápežovi. Diecézne kanonizácie definitívne ukončilo nariadenie Gregora IX. v roku 1234. Ním rezervoval vykonávanie kanonizačných procesov výlučne kompetencii Apoštolskej stolice. Súčastou týchto zmien bolo aj výrazné skomplikovanie kanonizačného procesu (Olexák 2006, 78; Krafft 2005, 2). Jedna z prvých uhorských svätíc, ktorá podliehala tomuto novému modelu kanonizácie bola sv. Alžbeta Uhorská, sestra uhorského krála Bela IV. Proces sa uskutočnil v roku 1235 a zachovala sa k nemu rozsiahla písomná agenda (Krafft 2004, 27-82). 
Biskup na území svojej diecézy mohol pri rôznych príležitostiach udelovat aj mimoriadne privilégiá a práva či už jednotlivcom (klerikom i laikom), alebo celým cirkevným inštitúciám (spoločenstvám). Medzi najznámejšie patrilo udelovanie odpustkov (indulgencií) kostolom. Často ich na žiadost predstavitelov cirkevných inštitúcií vydávali rímski kardináli. V mnohých prípadoch ich konfirmoval miestny ordinár, ${ }^{54}$ alebo ich sám vydával. ${ }^{55}$ Odpustkové listiny boli vydávané pod autoritou jedného alebo viacerých prelátov. ${ }^{56} \mathrm{~V}$ princípe išlo o právo, ktorým disponoval každý biskup (Hledíková 2002, 141). Podla nariadenia Štvrtého lateránskeho koncilu mohol jeden či viacerí biskupi udelit odpustky len na obdobie nie viac ako jedného roka v prípade konsekrácie bazilík a maximálne štyridsiatich dní pri príležitosti výročia posviacky tak, ako ich udeloval aj rímsky biskup, držitel' plnosti moci v cirkvi (DSP II 2007, IV. LK, čl. 62.6, 306).

Osobitné privilégiá biskupov sa vztahovali aj na niektoré liturgické slávenia. Sväté omše mohli byt’ v súlade s cirkevnými normami vysluhované len na posvätenej pôde a v sakrálnych objektoch. Biskup bol ale oprávnený udelovat právo používania prenosného oltára, na ktorom mohla byt' vysluhovaná sviatost' eucharistie. Takúto milost' dával predovšetkým laikom z najvyšších kruhov. V prípade, že dostali povolenie na používanie prenosného oltára, mohol im pri nich kňaz, ktorý ich sprevádzal na cestách, vysluhovat svätú omšu na špeciálnom prenosnom (cestovnom) oltári. ${ }^{57}$

K právam biskupa patrilo aj schvalovanie a potvrdzovanie najrôznejších vnútorných predpisov pre cirkevné inštitúcie. Stretávame sa s tým, že biskupi potvrdzovali štatúty konfraternít, ${ }^{58}$ reholných rádov ${ }^{59}$ alebo kapitúl kanonikov. ${ }^{60}$

Vzhl’adom na velké problémy, ktoré spôsobovali potulní klerici, ktorí často vyberali almužny a pritom šírili „rôzne bludy a sektárske učenia“ snažili sa cirkevné autority držat túto ich činnost̄

$\overline{54}$ Listinou z 10.5. 1340 ich pre kapitulný kostol v Bratislave potvrdil ostrihomský arcibiskup Čanád: „Nos autem Chanadinus, Dei et apostolica gratia archiepiscopus Strigoniensis, locique eiusdem comes perpetuus, predictis indulgenciarum venerabilium patrum largicionibus diocesanum consensum adhibemus, quadraginta dierum indulgenciis, premissa caritativa salutaria opera impendentibus augmentantes, sigilli nostri appensione duximus confirmandum." (MES III 1924, č. 528, 365-366).

${ }_{55}$ Arcibiskup Čanád 1. 7. 1349 sám udeluje odpustky pre rovnaký kostol: „Nos vero ipsis, elemosinarum suarum largitoribus, de omnipotentis Dei misericordia, beatorumque Petri et Pauli apostolorum eius, necnon beati Adalberti martiris patroni nostri auctoritatibus confisi, quadraginta dierum indulgencias misericorditer in Domino elargimur." (MES III 1924, č. 916, 686).

${ }_{56}$ Napríklad štyridsatdenné odpustky pre kostol sv. Kláry v Trnave vydali 30. 7. 1301 kaločský arcibiskup Ján, jágerský biskup Ondrej, spišský biskup-prepošt Jakub a čanádsky biskup Anton (CDHA I 1878, č. 9, $14)$.

57 Napríklad ostrihomský arcibiskup Ján udelil 22. 7. 1398 právo používat prenosný oltár magistrovi Mikulášovi, synovi Mikuláša a jeho manželke: „Tuis itaque supplicationibus personaliter inclinati, ut liceat tibi habere altare portabile cum debita reverentia et honore; super quo in locis decentibus, mundis et honestis, ubi te, intra tamen nostre eiecesis limites descendere contigerit, temporibus presertim cum ecclesiam parochialem commode visitare non posses, per proprium aut alium idoneum presbiterum in tua et nobilis d. Agathe consortis tue presentia possis et valeas missarum solempna celebrari facere, sive tamen alieni iuris preiudicio, authoritate diecesana tenore presentium indulgemus." (CDH X/2 1834, č. CCCIX, 577-578).

58 Napríklad listina ostrihomského arcibiskupa Čanáda z 21. 10. 1348 pre liptovských farárov a rektorov kostolov (CDHA V 1887, č. 121, 243).

59 Ostrihomský arcibiskup Vavrinec v r. 1297 schvaluje konštitúcie rádu sv. Pavla pustovníka: „Dominus archiepiscopus praedictus constitutiones et regulares observantias religionis eorum, ratificavit, approbavit et confirmavit, tenore sui privilegij mediante, sic et nos per consequens eas ratificare - - dignaremur." (MES II 1882 , č. 421, 418).

${ }_{60}$ Napríklad štatúty Varadínskej kolegiálnej kapituly potvrdené biskupom Žigmundom Turzom 15. 12. 1508 (Solymosi 1992, 139). 
pod dohladom. Výber milodarov bol povolený len so súhlasom Apoštolskej stolice alebo diecézneho biskupa, ktorý k tomu dal listinné potvrdenie. Jeho vzor predkladá aj nariadenie Štvrtého lateránskeho koncilu (DSP II 2007, IV. LK, čl. 62.3-4, 304).

\section{Zhrnutie}

Biskupi patrili medzi elity stredovekej spoločnosti. Ich postavenie priamo vyplývalo z postavenia katolíckej cirkvi v spoločnosti. Počas celého stredoveku dochádzalo k spresňovaniu kanonického práva, ktoré upravovalo aj práva a povinnosti najvyšších cirkevných autorít. Niektoré z nich ostávali stabilné. Iné podliehali postupným zmenám vyplývajúcim z premien v celej spoločnosti. Práva a povinnosti biskupov v cirkvi ponúkajú mimoriadne širokú škálu tém, z ktorých viaceré boli načrtnuté aj v tejto štúdii. Tým, že stáli na hierarchicky najvyšších stupňoch cirkevnej správy mali aj najširšie kompetencie v rámci diecézy, ktorá im bola zverená. Prvý velký okruh predstavoval dohlad nad klérom. Ten začínal výberom potenciálnych klerikov, ktorí mali získat’ svätenia a pôsobit v pastorácii. Priamy dohlad nad ich disciplínou a mravmi väčšinou delegoval na svojich zástupcov. Postupne sa upevňovala aj autorita biskupov vo vztahu fundátorov k nimi zakladaným cirkevným benefíciám a ich personálnemu zabezpečeniu. Osobitnou témou sú súdne právomoci, ktoré biskupi vykonávali voči vlastným klerikom, a vo vybraných oblastiach aj voči laikom. Ich rozsah bol vo výraznej miere ovplyvnený dobovou politickou a spoločenskou situáciou. Tlak svetských autorít, predovšetkým panovníka oklieštoval mnohé z nich a presúval ich na mimocirkevné fóra. Dôležitým prejavom autonómneho postavenia každého diecézneho biskupa boli jeho zákonodarné právomoci. Biskupi mohli byt v prípade potreby pôvodcami partikulárneho kánonického práva, ktoré uplatňovali na im zverenom území. Nesmeli však, samozrejme, odporovat celocirkevnému kánonickému právu. Biskupom prináležal aj celý rad d’alších exkluzívnych právomocí. K typickým patrilo udelovanie odpustkov, schvalovanie štatútov cirkevných inštitúcií, udelovanie rôznych liturgických výnimiek (právo použivat prenosný oltár) a podobne. Rozsiahla skupina právomocí sa vzt’ahovala na laické obyvatel’stvo. V závažných prípadoch $\mathrm{k}$ nim patrilo aj vynášanie prísnych trestov jednotlivcom aj skupinám, ako exkomunikácia či interdikt, resp. ich rušenie. Tieto právomoci vyplývali zo základných úloh biskupa v cirkvi. Ten bol predovšetkým hlavným ochrancom čistoty katolíckeho učenia v diecéze, ako aj bojovníkom proti herézam. Zodpovedal za to, že tak laici, ako aj klerici, budú dodržiavat základné princípy morálky vyplývajúce z cirkevného učenia. Okrem toho existovalo široké spektrum právomocí, ktoré boli podriadené priamo Apoštolskému stolcu. Ich rozsah sa postupne menil v závislosti od zväčšovania suverenity pápežstva vo vztahu k svetským autoritám. V mnohých záležitostiach boli miestni biskupi len exekútormi pápežských rozhodnutí. Medzi najviditelnejšie príklady patrilo obsadzovanie benefícií, predovšetkým tých vyšších (posty biskupov, predstavených a členov kapitúl), ale aj nižších (exemptné farnosti). Pápežskému rozhodnutiu podliehal aj celý rad záležitostí manželského práva (napr. rozluka) alebo sviatostí (napr. právo na výber spovedníka). Velkým množstvom právomocí v diecéze súčasne disponoval tak diecézny biskup, ako aj apoštolský stolec. To sú témy, ktorým nemohol byt’ v práci venovaný väčší priestor. Osobitné zhodnotenie si vyžaduje aj postavenie arcibiskupa (metropolitu) voči sufragánnym biskupom. Či už ide o potvrdzovanie biskupských volieb, postavenie odvolacej inštancie biskupského súdu, riešenie súdnych sporov, v ktorých vystupujú sufragánni biskupi, alebo plnenie osobitných úloh z poverenia pápežov a ich zástupcov. Nevyhnutné je študovat práva a povinnosti biskupov vyplývajúce z univerzálneho kánonického práva vo svetle domácich uhorských pomerov a špecifík na dobových príkladoch. Je pritom potrebné mat’ stále na mysli dynamiku vývoja a premien, ktorým stredoveká spoločnost̉ neustále podliehala. Až tak bude možné túto problematiku uchopit a pochopit v celej šírke a híbke. 


\section{REFERENCES}

Bidovský, Eugen. 1976. Orgány stredovekého súdnictva v Uhorsku 1000 - 1526. In Slovenská archivistika, 11/2, 151-176.

CDH X/6. 1844. Fejér, Georgius (ed.). 1844. Codex diplomaticus Hungariae ecclesiasticus ac civilis $\mathrm{X} / 6$. Budae.

$C D H X / 2$. 1834. Fejér, Georgius (ed.). 1834. Codex diplomaticus Hungariae ecclesiasticus ac civilis $\mathrm{X} / 2$. Budae.

CDH I. 1829. Fejér, Georgius (ed.). 1829. Codex diplomaticus Hungariae ecclesiasticus ac civilis I. Budae.

CDHA V. 1887. Nagy, Imre (ed.). 1887. Anjoukori okmánytár. Codex diplomaticus Hungaricus Andegavensis IV. (1347 - 1352). Budapest.

CDHA IV. 1884. Nagy, Imre (ed.). 1884. Anjoukori okmánytár. Codex diplomaticus Hungaricus Andegavensis IV. (1340 - 1346). Budapest.

CDHA II. 1881. Nagy, Imre (ed.). 1881. Anjoukori okmánytár. Codex diplomaticus Hungaricus Andegavensis II. (1322 - 1332). Budapest.

CDHA I. 1878. Nagy, Imre (ed.). 1878. Anjoukori okmánytár. Codex diplomaticus Hungaricus Andegavensis I. (1301 - 1321). Budapest.

CDSL I. 1971. Marsina, Richard (ed.). Codex diplomaticus et epistolaris Slovaciae. Tomus 1. Bratislavae.

CIC II. 1959. Friedberg, Aemilius (ed.). 1959. Corupus iuris canonici II. Decretalium collectiones. Graz.

CIC I. 1959. Friedberg, Aemilius (ed.). 1959. Corupus iuris canonici I. Decretum magistri Gratiani. Graz.

DRMH II. 1992. BAK, János M. - ENGEL, Pál - ROSS SWEENEY, James (eds.). Decreta Regni Mediaevalis Hungariae. The Laws of the Medieaval Kingdom of Hungary 1301 - 1457. Volume II. Salt Lake City.

DRMH I. 1999. BAK, János M. - BÓNIS, György - ROSS SWEENEY, James (eds.). Decreta Regni Mediaevalis Hungariae. The Laws of the Medieaval Kingdom of Hungary 1000 - 1301. Volume I. Idyllwild.

DSP III. 2007. Baron, Arkadiusz - Pietras, Henryk (eds.). Dokumenty soborów powszechnych. Tom III (1414 - 1445). Kraków.

DSP II. 2007. Baron, Arkadiusz - Pietras, Henryk (eds.). Dokumenty soborów powszechnych. Tom II (869 - 1312). Kraków.

Elbel, Petr. 2007. Zlomek olomoucké konfirmační knihy z let 1452 - 1455. Předběžné výsledky rozboru opomíjeného pramene k poznání církevní topografie, diecézní správy a konfesního soužití na Moravě po polovine 15. století. In Hrdina, Jan - Zilynská, Blanka (eds.). Colloquia mediaevalia Pragensia 8. Církevní topografie a farní sít pražské církevní provincie v pozdním středověku. Praha,

Erdő, Péter. 2010. Právne postavenie Spišského prepoštstva v Ostrihomskej arcidiecéze. In Hromják, Luboslav (ed.). Z dejín Spišského prepoštstva. Zborník z medzinárodnej konferencie pri príležitosti 800 . výročia prvej známej písomnej zmienky o Spišskom prepošstve. Spišské Podhradie, 23-29.

Erdö, Péter. 2005. Kirchenrecht im mittelalterlichen Ungarn. Gesammelte Studien. Berlin.

Erdö, Péter. 1993. Libri sinodali tardo medievali in Ungheria. Il libro sinodale d'Esztergom. In REDC 50, 607-622.

Érszegi, Géza. 1994. Püspök. In Engel, Pál - Makk, Ferenc (eds.). Korai magyar történeti lexikon (9 - 14. Század). Budapest, 563-564. 
Eubel, Conradus. 1914. Hierarchia catholica medii aevi. Volumen II. Monasterii.

Fedeles, Tamás. 2010. Középkori pécsi segédpüspökök. In Magyar egyháztörténeti vázlatok, 2010/1-2, 5-20.

Feňarová, Magda. 1964. Spišské prepoštstvo. Stredoveké listiny 1248 - 1526. Inventár. Bratislava.

Fraknói, Vilmos. 1899. Genealogiai kérdések (Pór Antalnak ajánlva.). In Turul, 17/3, 135-138.

Fraknói, Vilmos. 1892. Oklevelek a papi levéltárakból. (Függelékül a »Nyomozások a pápai levéltárakban« czímű s a Századok f. évi II. és III. füzeteiben közlőtt czikkhez.). In Történelmi tár, 385-401.

Hišem, Cyril - Fedorčák, Peter (eds.). 2007. Kanonické vizitácie po Tridentskom koncile. Zborník príspevkov z medzinárodnej konferencie, Košice 9. novembra 2006. Košice.

Hlavačková, Miriam. 2017. K zbožnosti na stredovekých hradoch. In Dvořáková, Daniela (ed.). Stredoveké hrady na Slovensku. Život, kultúra, spoločnost'. Bratislava, 115-125.

Hledíková, Zdeňka. 2002. Biskup. In Nodl, Martin - Šmahel, František (eds.). Člověk českého středověku. Praha, 139-165.

Hrdina, Ignác A. (ed. et transl.). 2015. Dokumenty Tridentského koncilu. Latinský text a preklad do češtiny. Praha.

Hrdina, Jan. 2009. Jak klerik k beneficiu přišel. Uvádění duchovních k nižším obročím ve střední Evropě ve 14. - 15. Století. In Nodl, Martin - Šmahel, František (eds.). Rituály, ceremonie a festivity ve střední Evropě 14. a 15. století. Colloquia mediaevalia Pragensia XII. Praha, 347-364.

Chaloupecký, Václav. 1928. Slovenské dioecese a tak řečená apoštolská práva. In Bratislava. Časopis učené společnosti Šafaříkovy. Bratislava, II, 1-69.

Juck, Ludovít (ed.). 1984. Výsady miest a mestečiek na Slovensku I. (1238 - 1350). Bratislava.

Kalous, Antonín. 2014. Biskupské a legátské rituály a ceremonie. In Nodl, Martin - Šmahel, František (eds.). Slavnosti, ceremonie a rituály v pozdním středověku. Praha, 317-367.

Kalous, Antonín. 2010. Plentitudo potestatis in partibus? Papežští legáti a nunciové ve střední Evropé na konci středověku (1450 - 1526). Brno.

Knappek, Ludevit. 1934. Obsadzovanie uhorských biskupstiev od X. do konca XIV. storočia so zvláštnym zretelom na pápežské zásahy a na postavenie uhorských králov. Bratislava.

Krafl, Pavel (ed.). 2014. Synody a statuta Olomoucké diecéze v období středověku. Praha.

Krafft, Otfried. 2005. Papsturkunde und Heiligsprechung. Die päpstlichen Kanonisationen vom Mittelalter bis zur Reformation. Köln - Weimar - Wien.

Krafft, Otfried. 2004. Kommunikation und Kanonisation. Die Heiligsprechung der Elisabeth von Thüringen 1235 und das Problem der Mehrfachausfertigung päpstlicher Kanonisationsurkunden seit 1161. In Zeitschrift des Vereins für Thüringische Geschichte 58, 27-82.

Kruppa, Nathalie - Zygner, Leszek (eds.). 2006. Partikularsynoden im späten Mittelalter. Göttingen. Kušik, Michal. 1961. Cirkevný desiatok. In Historický časopis 9/3, 462-467.

Labanc, Peter. 2015. Počiatky úradu vikára spišského prepošta. In Rábik, Vladimír (ed.). Studia Historica Tyrnaviensia XVII. Trnava, 66-88.

Labanc, Peter - Glejtek, Miroslav. 2015. Spišské prepoštstvo na prelome stredoveku a novoveku I. Príspevok k náboženským dejinám Spiša. Trnava - Kraków.

Lakatos, Bálint. 2015. Spor bratislavského prepošta a kapituly v rokoch 1421 - 1425. In Rábik, Vladimír (ed.). Studia Historica Tyrnaviensia XVII. Pramene k dejinám cirkevnej správy. Trnava - Kraków, 161-179.

Lakatos, Bálint - Mikó, Gábor. 2015. Fungovanie cirkevného súdnictva v stredovekom Uhorsku. Ostrihomský tribunál v rokoch 1399 - 1428. In Kultúrne dejiny, 6/1, 28-45.

Lehotská, Darina. 1972. Príručka diplomatiky. Bratislava. 
Lopatková, Zuzana. 2014. Kanonické vizitácie severozápadnej časti Podhorského dekanátu v 2. polovici 16. storočia. Trnava.

Lukačka, Ján. 2011. Hrad stredobodom mocenských záujmov. In Judák, Viliam - Bednár, Peter - Medvecký, Jozef (eds.). Kolíska krestanstva na Slovensku. Nitriansky hrad a Katedrála sv. Emeráma v premenách času. Nitra, 122-133.

Lukcsics, Pál. 1931. XV. szádi pápák oklevelei. I. V. Márton pápa (1417 - 1431). Budapest.

Marek, Miloš. 2010. Formovanie farskej siete na území Nitrianskej župy v stredoveku. In Rábik, Vladimír a kol. Vývoj cirkevnej správy na Slovensku. Krakov, 132-215.

Marsina, Richard. 2010. Vývoj cirkevnej organizácie v staršom stredoveku (od najstarších čias do začiatku 12. storočia). In Rábik, Vladimír a kol. Vývoj cirkevnej správy na Slovensku. Krakov, 15-28.

Marsina, Richard (ed.). 2003. V královstve svätého Štefana. Pramene k dejinám Slovenska a Slovákov III. Bratislava.

Marsina, Richard (ed.). 1997. Legendy stredovekého Slovenska. Ideály stredovekého človeka očami cirkevných spisovatelov. Budmerice.

Marsina, Richard. 1990. Prvé obdobie uhorského diplomatického vývoja. In Slovenská archivistika 25/2, 8-20.

Marsina, Richard. 1989. Štúdie k Slovenskému diplomatáru II. Bratislava.

Marsina, Richard. 1973. Štúdie k Slovenskému diplomatáru I/2. In Historické štúdie XVIII. Bratislava, 5-119.

Malovecká, Milota. 2006. K uhorským cirkevným synodám v stredoveku (s podrobnou analýzou provinciálnej synody konanej v Dvoroch nad Žitavou). In Slivka, Michal - Homza, Martin (eds.). Studia archaeologica Slovaca mediaevalia V. Človek - sacrum - prostredie. Levoča, 197-206.

Mályusz, Elemér. 2007. Egyházi társadalom a középkori Magyarországon. Budapest.

Marek, Miloš. 2012. Uhorské královstvo na začiatku 14. storočia a misia pápežského legáta kardinála Gentilisa. In Uličný, Ferdinand - Magdoško, Drahoslav (eds.). Bitka pri Rozhanovciach v kontexte slovenských a uhorských dejín. Košice, 4-52.

Melǐ̌, Bernard Jozef. 2016. Cirkevné výsady miest a mestečiek v stredoveku na Slovensku. In Historický zborník, 26/2, 2016, 26-47.

MES III. 1924. DEDEK, Ludovicus (ed.). Monumenta Ecclesiae Strigoniensis. Tomus III. Strigonii. MES II. 1882. KNAUZ, Ferdinandus (ed.). Monumenta Ecclesiae Strigoniensis. Tomus II. Strigonii. MES I. 1874. KNAUZ, Ferdinandus (ed.). Monumenta Ecclesiae Strigoniensis. Tomus I. Strigonii. Mrkývka, Petr - Veselá, Renata. 1992. Vybrané otázky z dějin kanonického práva. Brno.

Múcska, Vincent. 2007. Cirkevné zákony Štefana I. Svätého. In Simon, Attila (ed.). Acta historica Danubiensia I. Komárno, 11-17.

Múcska, Vincent. 2004. Uhorsko a cirkevné reformy 10. a 11. storočia. Bratislava.

Olejník, Vladimír. 2015. Spišské prepoštstvo na prelome stredoveku a novoveku II. Visitatio Ecclesiarum terrae Scepusiensis 1655 - 1656. Trnava - Kraków.

Olexák, Peter. 2006. Kult relikvií a svätcov. In Slivka, Michal - Homza, Martin (eds.). Studia archaeologica Slovaca mediaevalia V. Človek - sacrum - prostredie. Levoča, 75-82.

Oslanský, František. 1987. Význam cirkevných desiatkov v stredoveku na Slovensku. In Historický časopis 35/6, 361-370.

Péterffy, Carolus (ed.). 1741. Sacra concilia ecclesiae romano-catholicae in regno Hungariae celebrate ab anno Christi MXVI usque ad annum MDCCXV. Pars I. Posonii.

Pór, Antal. 1889. Kálmán, győri püpök (1317 - 1375). In Századok V, 369-384.

Rábik, Vladimír (ed.). 2014. Monumenta Vaticana Slovaciae. Tomus IV. Camera apostolica 1 (Libri formatarum 1425 - 1524). Trnavae - Romae. 
Rábik, Vladimír (ed.). 2009. Monumenta Vaticana Slovaciae. Tomus II. Registra supplicationum ex actis pontificum Romanorum res gestas Slovacas illustrantia. Volumen 1 (1342 - 1415). Trnavae - Romae.

RDSL II. 1987. Sedlák, Vincent (ed.). Regesta diplomatica nec non epistolaria Slovaciae. Tomus 2. Bratislavae.

Ruttkay, Alexander. 2016. O počiatkoch krestanstva na území Slovenska, význame cyrilo-metodskej misie a jej odozvách v 10. - 11. storočí [On the Origins of Christianity in the Territory of the Slovak Republic, Significance of Missionary Work of Cyril and Methodius and Responses to it in the 10th - 11th Centuries]. In Konštantínove listy [Constantine's Letters] 9/2, 2-10.

Solymosi, László. 1992. Az egri káptalan dékánválasztási statútumai a XV. századból. In Léveltári Közlemények, 63/1-2, 137-161.

Szentirmai, Alexander. 1961. Die ungarische Diözesansynode im Spätmittelalter. In Zeitschrift der Savigny-Stiftung für Rechtsgeschichte. Weimar, 266-292.

Šimončič, Jozef-Karabová, Katarína. 2015. Kanonické vizitácie Dunajeckého dekanátu v Spišskom biskupstve z roku 1832. Kraków.

Šotník, Stanislav. 2001. Hospodárske a majetokovoprávne vztahy pri správe fár na Slovensku do polovice 14. storočia. In Slovenská archivistika 36/1, 41-58.

Šotník, Stanislav. 1999. Zakladacia listina fary v Ponikách z roku 1310. In Slovenská archivistika, 34/1, 36-54.

Šotola, Jaroslav. 2007. Kariéra v černém. Předpoklady pro získání farního beneficia v 18. století. In Časopis Matice moravské, 126/2, 319-341.

Theiner, Augustin. 1860. Vetera monumenta historica Hungariam sacram illustrantia. Tomus II. Romae.

Theiner, Augustin. 1859. Vetera monumenta historica Hungariam sacram illustrantia. Tomus I. Romae.

Wagner, Carolus (ed.). 1774. Analecta Scepusii sacri et profani. Pars I. Viennae.

Tomko, Jozef. 1995. Zriadenie Spišskej, Banskobystrickej a Rožňavskej diecézy a královské patronátne právo v Uhorsku. Spišské Podhradie.

Tóth, Norbert, C. 2014. Magyarország késő-középkori föpapi archontológiája (1458-1526). (Érsekek, püspökök, segédpüspökök, vikáriusok, valamint jövedelemkezelők). Budapest.

Uličný, Ferdinand. 2013. Dejiny Slovenska v 11. až 13. storočí. Bratislava.

Vladár, Vojtech. 2017. Dejiny cirkevného práva. Trnava.

Vladár, Vojtech. 2009. Pramene práva katolíckej cirkvi v historickom vývoji. Plzeň.

\section{Zoznam skratiek}

cap. = kapitola

Col. $=$ Koloman $(\mathrm{král})$

č. = číslo

čl. = článok

hl. = hlava

Lad. = Ladislav I. (král)

lib. = liber

LK = Lateránsky koncil

OstS = Ostrihomská synoda

SabS = Sabolčská synoda

tit. $=$ titulus 
SUMMARY: THE RIGHTS AND DUTIES OF BISHOPS FROM THE KINGDOM OF HUNGARY IN THE ADMINISTRATION OF DIOCESES IN THE 11TH - 14TH CENTURIES AS RELATED TO THE CANON LAW. The text deals with the most important rights and duties of medieval bishops as defined by canon law. Although many of them were subject to change, several basic tasks of the bishops remained unchanged. The study does not deal with the authority of the bishops that arose from their position in the sacral area (in pontificalibus). Attention is paid to their authority in the area of religious governance (in spiritualibus) and property administration (in temporalibus). Firstly, it discusses the process of episcopal ordination. Only a proper authorization enables the bishop to acquire the abovementioned powers. One of the essential authorities assigned to a bishop is the administration of ecclesiastical property. Gradually, the bishops gained increasing influence on the conduct of their patrons. The rights of secular patrons to manipulate with the property freely were slowly limited. The episcopal supervision of their occupation became stricter. Bishops were responsible for supervision of the proper conduct of church institutions in the diocese. Similarly, all the clerics who worked with them were subject to their supervision. This is closely connected with the bishops jurisdiction over clerics and in selected areas, over laymen as well. In case of violation of the norms of canon law and the principles of Christian morality, they could also administer the most severe punishments (excommunication, interdict). Bishops also had different rights. These included the right to grant indulgences, to approve the statutes of church institutions, to regulate some liturgical affairs, etc. They themselves acted as legislators of their own diocese. They could approve their own particular norms of canon law at church synods. Metropolitan bishops had special powers. They represented the appellate jurisdiction of bishops' courts. They have resolved various disputes between suffragan bishops and others. In addition, they had an influence on the occupation of the posts of the suffragan bishops (they confirmed them). The issue of bishops' rights and duties is extremely broad so the presented study focuses only on the most important ones. Many of them are confronted with specific examples from the Hungarian environment.

doc. PhDr. Ing. Miroslav Glejtek, PhD.

Constantine the Philosopher University in Nitra

Faculty of Arts

Department of History

Hodžova 1

94974 Nitra

Slovakia

mglejtek@ukf.sk 